\title{
Environmental forcing on zooplankton distribution in the coastal waters of the Galápagos Islands: spatial and seasonal patterns in the copepod community structure
}

\author{
Diego F. Figueroa ${ }^{1,2, *}$ \\ ${ }^{1}$ College of Ocean and Atmospheric Sciences, Oregon State University, Corvallis, OR 97331, USA \\ ${ }^{2}$ Present address: School of Earth, Environmental and Marine Sciences, University of Texas Rio Grande Valley, Brownsville, \\ TX 78520, USA
}

\begin{abstract}
The oceanographic setting of the Galápagos Archipelago results in a spatially diverse marine environment suitable for a variety of species with different climatic requirements. The goal of this study is to demonstrate that the community of zooplankton in the Galápagos is highly structured by regional differences in productivity patterns and advective sources. Results are mostly based on biodiversity patterns of the copepod community collected over the Galápagos shelf between 2004 and 2006. Two contrasting marine environments were observed: a nutrientrich upwelling system with a shallow mixed layer and a diatom-dominated phytoplankton community in the west, and a non-upwelling system with a deeper mixed layer, lower surface nutrient concentrations, and a phytoplankton community dominated by small cells in the east. These conditions drive spatial structuring of zooplankton that varies seasonally, with 3 distinct copepod communities separated geographically in western, central, and southeastern regions. The western upwelling region has a high-abundance and low-diversity community, whereas the nonupwelling eastern region has a lower-abundance and higher-diversity community. The eastern community is further differentiated into central and southeastern regions, the former with tropical species advected from the north, the latter with temperate species advected from the south. During the warm season, when the equatorial front moves south, species typical of the central region spread southwest across the archipelago. This is the first taxonomically comprehensive list of copepod species for the Galápagos Islands. A total of 164 copepod species are identified, including 22 species previously unreported from the Eastern Tropical Pacific.
\end{abstract}

KEY WORDS: Copepoda $\cdot$ Biodiversity $\cdot$ Oceanography $\cdot$ Biogeography $\cdot$ Eastern Tropical Pacific

\section{INTRODUCTION}

The Galápagos Islands are a series of volcanic islands located along the equator about $900 \mathrm{~km}$ off the coast of Ecuador, within the Eastern Tropical Pacific (ETP). The islands are under the influence of various ocean currents and water masses with distinct characteristics, resulting in a spatially diverse

\footnotetext{
*Corresponding author: diego.figueroa@utrgv.edu
}

marine environment that varies seasonally (Harris 1969, Glynn \& Wellington 1983, Edgar et al. 2004, Palacios 2004, Sweet et al. 2007, Liu et al. 2014). This diverse marine environment provides suitable habitats for a variety of species with different climatic requirements, evident from the distinct types of marine mammals, seabirds, and fish that inhabit the Galápagos Archipelago (Harris 1969, Jackson 1993,

() The author 2021. Open Access under Creative Commons by Attribution Licence. Use, distribution and reproduction are unrestricted. Authors and original publication must be credited. 
Edgar et al. 2004). Based on sea water temperature, Harris (1969) divided the archipelago into 5 regions (north, west, south, central, and central mixing). These were largely confirmed by Edgar et al. (2004) based on community structure of macroinvertebrates and reef-associated fish, with 1 key distinction: the south, central, and central mixing regions defined by Harris (1969) were combined into 1 central-southeastern bioregion.

The regional divisions of the Galápagos marine environment by both Harris (1969) and Edgar et al. (2004) agree with the general oceanographic setting of the Galápagos. Four main currents converge in the Galápagos: the eastward-flowing Equatorial Undercurrent (EUC) and the westward-flowing South Equatorial Current (SEC), which is fed by the Panama Current in the north and the Peru Current in the south (Palacios 2004, Kessler 2006, Sweet et al. 2007, Schaeffer et al. 2008, Liu et al. 2014, Glynn et al. 2017). These currents generate 4 distinct zones in the Galápagos marine environment (Harris 1969, Glynn \& Wellington 1983): (1) a warm tropical zone in the north caused by advection of warm waters from Central America by the Panama Current feeding into the $\mathrm{SEC}_{i}(2)$ a cool zone in the south due to advection of cold, upwelled, waters from the South American continent by the Peru Current feeding into the $\mathrm{SEC}_{\boldsymbol{i}}(3)$ a cooler zone in the west from topographically induced upwelling of the $\mathrm{EUC}_{i}$ and (4) a central zone with seasonally varying conditions. The seasonality is driven by the latitudinal movement of the Intertropical Convergence Zone (ITCZ), centered around $4^{\circ} \mathrm{N}$ in December-January and $10^{\circ} \mathrm{N}$ in July-August (Glynn et al. 2017). Two water masses straddle the Galápagos: the warm, low-salinity Tropical Surface Water (TSW, temperature $[\mathrm{T}]>25^{\circ} \mathrm{C}$, salinity $[\mathrm{S}]<34 \mathrm{ppt}$ ) in the north and the cold, highsalinity Equatorial Surface Water $\left(\mathrm{ESW}, \mathrm{T}<25^{\circ} \mathrm{C}, \mathrm{S}>\right.$ $34 \mathrm{ppt}$ ) in the south (Glynn et al. 2017). Strengthening of the Southeast Trade Winds during the austral winter moves the ITCZ to its northernmost point, bringing the entire Galápagos Archipelago under their influence, resulting in lower sea surface temperatures (SSTs) across the archipelago by extending ESW to the north and strengthening the advection of water from the Peru Current into the SEC (Schaeffer et al. 2008, Liu et al. 2014, Glynn et al. 2017). Conversely, the weakening of the Southeast Trade Winds during the austral summer moves the ITCZ to its southernmost point, bringing the Northeast Trade Winds to the north of the archipelago, resulting in higher SSTs across the Galápagos by extending the TSW to the south and increasing the contribution of the Panama Current to the SEC (Schaeffer et al. 2008, Liu et al. 2014, Glynn et al. 2017). The influence of this dynamic and diverse marine environment is clearly evident in larger fauna, showing well defined biogeographic patterns (Jackson 1993, Edgar et al. 2004). Whether similar patterns also apply to planktonic organisms, such as zooplankton, remains largely unknown.

Zooplankton play a crucial ecological role in the marine environment by providing a direct link between primary producers and higher trophic levels. Very little research has been conducted on zooplankton in the Galápagos Islands, and the few studies that do exist are taxonomically limited (Grice 1964, Arcos 1981, García et al. 1993, Figueroa \& Hoefel 2008, Figueroa 2011). Most of these are descriptions of new species (Grice 1964, Figueroa \& Hoefel 2008, Figueroa 2011), while Arcos (1981) focused on a single copepod species, Acartia levequei, and Garcia et al. (1993) focused on zooplankton biomass with only broad taxonomic distinction by major taxonomic groups (Copepoda, Ostracoda, Euphausiacea, Pteropoda, Chaetognatha, Thaliacea, and Larvacea). While extensive zooplankton work has been done in other regions of the ETP, a comprehensive study of Galápagos zooplankton has not been realized until the present research. The dynamic and diverse marine environment of the Galápagos Islands provides an ideal setting for investigating the environmental drivers of zooplankton distribution and community structure in a relatively small geographic area $(300 \mathrm{~km})$ within the ETP.

The first major oceanographic expeditions in the ETP were carried out on the US Fish Commission Steamer 'Albatross' during 1888-1905 (FernandezAlamo \& Färber-Lorda 2006). Plankton collected by net tows during these expeditions led to the publication of numerous taxonomic descriptions of zooplanktonic species, including descriptions of the Copepoda by Giesbrecht (1895). After the 'Albatross' expeditions, several smaller expeditions increased the taxonomic knowledge of zooplankton species assemblages in the region, but it was not until 1967, when the EASTROPAC project was initiated, that the ETP was again extensively studied, spurring numerous publications on zooplankton taxonomy and the pelagic ecology of the ETP region (Blackburn et al. 1970, Ahlstrom 1971, Beers \& Stewart 1971, Longhurst \& Seibert 1972, Longhurst 1976, Fernandez-Alamo 1983, Segura-Puertas 1984, Arcos \& Fleminger 1986). Out of this flurry of research within the ETP, Arcos \& Fleminger (1986) came the closest to the Galápagos, sampling $300 \mathrm{~km}$ to the east and 
$700 \mathrm{~km}$ to the west of the archipelago. After EASTROPAC, small-scale sampling of zooplankton in the ETP has occurred, with the most recent, intensive taxonomic work being carried out near the Pacific coast of Mexico (Fernandez-Alamo 2000, SuárezMorales et al. 2000).

Two main types of zooplankton community structure studies have been carried out in the ETP; one involves long-distance transects (thousands of kilometers), usually carried out along a productivity gradient (e.g. Brinton 1979, Fernandez-Alamo \& FärberLorda 2006, Décima et al. 2011, Hirai \& Tsuda 2015), and the other focuses on small areas (tens of kilometers) or time series, usually looking at seasonal effects on zooplankton productivity (Manríquez et al. 2009, Ambriz-Arreola et al. 2012, 2018, Gasca et al. 2012, Hidalgo et al. 2012, Kozak et al. 2014). These ecological studies have demonstrated that upwelling is a key driver of zooplankton community structure, resulting in distinct communities in non-upwelling and upwelling systems. In the Galápagos, the presence of a persistent upwelling system in the west and a seasonally varying system in the east provides the environmental contrast to compare community structure of zooplankton along a geographic gradient and through seasonal effects.

I hypothesized that the community differences in zooplankton will be driven by differences in productivity between the upwelling system in the west and the non-upwelling system in the east. These differences should be further modulated by advective sources. Finally, since the seasonality of the Galápagos marine environment will affect both local conditions such as upwelling and sources of advected waters, the zooplankton community should show a response to these changes. Therefore the following patterns are expected: (1) There should be a high contrast of environmental variables between the western upwelling region and the eastern non-upwelling region, with distinct zooplankton species-specific responses to these variables; (2) the western upwelling region should have higher abundances with a community primarily dominated by a few species compared to the eastern non-upwelling region, which should have lower abundances and higher diversity; (3) the eastern community should be further modulated by advective sources, with a greater presence of tropical species in the central region due to its proximity to TSW and influence of the Panama Current, and a unique southeastern community influenced by advection from the Peru Current of South American coastal upwelling waters; and (4) the zooplankton community should respond to seasonality, reflecting both environmental changes and changes in advective sources resulting in a decreased zooplankton abundance in the west when upwelling subsides during the warm season, accompanied by an influx of species from the eastern region as the warmer water mass from the northeast moves southwest across the archipelago.

\section{MATERIALS AND METHODS}

\subsection{Field sampling}

Most of the field sampling was performed aboard the PV 'Guadalupe River,' a Galápagos National Park Service patrol vessel, during September 2004, November 2004, February 2005, May 2005, and July 2005 at 21 sampling sites (Fig. 1). These were samples of opportunity obtained as the PV 'Guadalupe River' patrolled the Galápagos Marine Re-

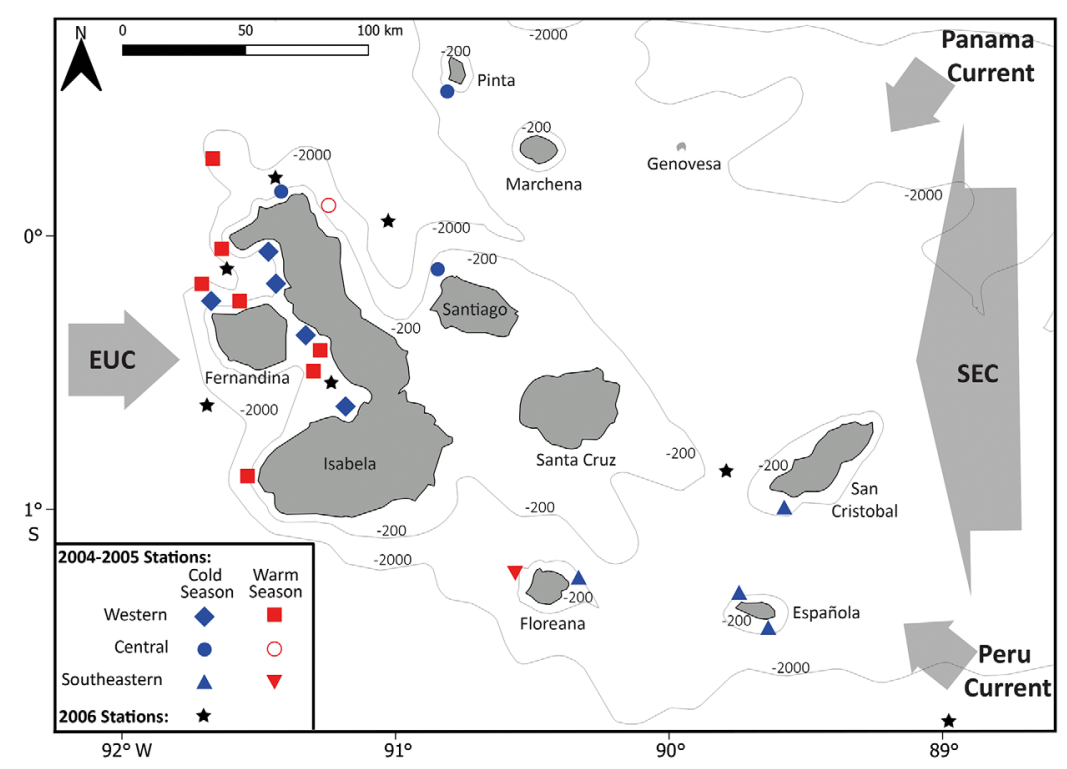

Fig. 1. Galápagos Islands, showing stations sampled during the cold (blue) and warm (red) seasons from the PV 'Guadalupe River' in September 2004, November 2004, February 2005, May 2005, and July 2005. Stars mark stations sampled from the RV 'Thompson' in January 2006, all during a transitional period from the cold to the warm season. EUC: Equatorial Undercurrent; SEC: South Equatorial Current 
serve. Therefore, it was not possible to obtain hydrographic data. Zooplankton samples were collected by vertical tows over the Galápagos shelf from a depth range of $110-200 \mathrm{~m}$ to the surface (Fig. 1, Table 1). Most tows were taken from near the seafloor, except for 4 sites where depth was $\geq 200 \mathrm{~m}$ (Table 1). A simple ring net of $1 \mathrm{~m}$ mouth diameter and $100 \mu \mathrm{m}$ mesh was used for sampling mesozooplankton at each station. Additional sampling was performed aboard the RV 'Thompson' from 13 to 28 January 2006 at 7 sampling sites: 3 in the western and 4 in the eastern region of the archipelago (Fig. 1). Samples were taken by vertical tows from $180 \mathrm{~m}$ depth to the surface also using a $100 \mu \mathrm{m}$ mesh ring net with $1 \mathrm{~m}$ mouth dia- meter. Only 2 of these sampling stations were over the Galápagos shelf, the rest were in oceanic waters with depths over $2000 \mathrm{~m}$ (Table 1). All zooplankton samples were preserved in a $10 \%$ formalin solution.

Hydrographic data were collected to demonstrate the high contrast in environmental variables between the upwelling system in the western region and the non-upwelling system in the eastern region. These data were collected over 7 sites ( 3 in the west and 4 in the east) sampled during the RV 'Thompson' research cruise from 13 to 28 January 2006 (Table 1, Fig. 1). Water samples were taken with a 24-bottle CTD rosette. Hydrographic measurements included salinity, temperature, pressure, chlorophyll a $(\mathrm{chl} \mathrm{a})$

Table 1. Location, date, time, tow depth, and seafloor depth for all hydrographic and zooplankton sampling sites in the Galápagos Archipelago for the 2004-2005 PV 'Guadalupe River' and 2006 RV 'Thompson' cruises. Sites are divided according to the season (cold or warm) and according to their location within the archipelago (western, central, or southeastern regions)

\begin{tabular}{|c|c|c|c|c|c|c|c|c|}
\hline $\begin{array}{l}\text { Region/ } \\
\text { Season }\end{array}$ & Site name & Site ID & Latitude & Longitude & $\begin{array}{c}\text { Date } \\
\text { (mm/dd/yyyy) }\end{array}$ & $\begin{array}{c}\text { Time } \\
\text { (h) }\end{array}$ & $\begin{array}{l}\text { Tow depth } \\
\text { (m) }\end{array}$ & $\begin{array}{c}\text { Seafloor } \\
\text { depth (m) }\end{array}$ \\
\hline \multicolumn{9}{|c|}{ PV ‘Guadalupe River’ } \\
\hline \multicolumn{9}{|c|}{ Western region } \\
\hline \multirow{5}{*}{ Cold } & Canal Bolivar & CBo9 & $0.28^{\circ} \mathrm{S}$ & $91.79^{\circ} \mathrm{W}$ & 9/5/2004 & $08: 13$ & 170 & 175 \\
\hline & Punta Moreno & PMo11 & $0.69^{\circ} \mathrm{S}$ & $91.36^{\circ} \mathrm{W}$ & $11 / 13 / 2004$ & $07: 33$ & 120 & 130 \\
\hline & Caseta & Cas11 & $0.35^{\circ} \mathrm{S}$ & $91.35^{\circ} \mathrm{W}$ & $11 / 14 / 2004$ & $07: 36$ & 125 & 131 \\
\hline & West Fernandina & Fer11 & $0.29^{\circ} \mathrm{S}$ & $91.58^{\circ} \mathrm{W}$ & $11 / 15 / 2004$ & $15: 44$ & 185 & 185 \\
\hline & Punta Brava & PBr11 & $0.08^{\circ} \mathrm{S}$ & $91.41^{\circ} \mathrm{W}$ & $11 / 16 / 2004$ & $11: 09$ & 200 & 287 \\
\hline \multirow[t]{7}{*}{ Warm } & Canal Bolivar & $\mathrm{CBo} 2$ & $0.37^{\circ} \mathrm{S}$ & $91.35^{\circ} \mathrm{W}$ & 2/3/2005 & 08:11 & 150 & 168 \\
\hline & South Isabela & SIs2 & $0.92^{\circ} \mathrm{S}$ & $91.53^{\circ} \mathrm{W}$ & $2 / 18 / 2005$ & $09: 22$ & 125 & 200 \\
\hline & North Isabela & NIs2 & $0.07^{\circ} \mathrm{S}$ & $91.56^{\circ} \mathrm{W}$ & $2 / 19 / 2005$ & $06: 33$ & 125 & 152 \\
\hline & Roca Redonda & RRe5 & $0.28^{\circ} \mathrm{N}$ & $91.64^{\circ} \mathrm{W}$ & $5 / 20 / 2005$ & $14: 48$ & 185 & 230 \\
\hline & Fernandina Cabo Douglas & FCD5 & $0.29^{\circ} \mathrm{S}$ & $91.64^{\circ} \mathrm{W}$ & $5 / 21 / 2005$ & $17: 35$ & 180 & 200 \\
\hline & Cabo Douglas & CDo5 & $0.29^{\circ} \mathrm{S}$ & $91.64^{\circ} \mathrm{W}$ & $5 / 24 / 2005$ & $17: 35$ & 180 & 200 \\
\hline & Punta Mangle & PMa5 & $0.40^{\circ} \mathrm{S}$ & $91.37^{\circ} \mathrm{W}$ & $5 / 22 / 2005$ & $17: 06$ & 150 & 176 \\
\hline \multicolumn{9}{|c|}{ Central region } \\
\hline Warm & Northeast Isabela & NEIs5 & $0.13^{\circ} \mathrm{N}$ & $91.31^{\circ} \mathrm{W}$ & $5 / 19 / 2005$ & $16: 36$ & 185 & 250 \\
\hline \multirow[t]{3}{*}{ Cold } & North Bucanero & NBu7 & $0.14^{\circ} \mathrm{S}$ & $90.82^{\circ} \mathrm{W}$ & $7 / 24 / 2005$ & $07: 55$ & 180 & 180 \\
\hline & Pinta & Pin 7 & $0.59^{\circ} \mathrm{N}$ & $90.80^{\circ} \mathrm{W}$ & $7 / 25 / 2005$ & $12: 39$ & 145 & 145 \\
\hline & North Isabela & NIs7 & $0.11^{\circ} \mathrm{N}$ & $91.47^{\circ} \mathrm{W}$ & $7 / 27 / 2005$ & $10: 49$ & 185 & 185 \\
\hline \multicolumn{9}{|c|}{ Southeastern region } \\
\hline Warm & Floreana & Flo5 & $1.25^{\circ} \mathrm{S}$ & $90.53^{\circ} \mathrm{W}$ & 5/18/2005 & $11: 51$ & 155 & 155 \\
\hline \multirow[t]{4}{*}{ Cold } & East Floreana & EFl11 & $1.29^{\circ} \mathrm{S}$ & $90.34^{\circ} \mathrm{W}$ & $11 / 12 / 2004$ & 09:08 & 110 & 116 \\
\hline & San Cristobal & SCr11 & $0.98^{\circ} \mathrm{S}$ & $89.56^{\circ} \mathrm{W}$ & $11 / 17 / 2004$ & $11: 12$ & 68 & 68 \\
\hline & South Espanola & SEs11 & $1.43^{\circ} \mathrm{S}$ & $89.66^{\circ} \mathrm{W}$ & $11 / 18 / 2004$ & $08: 33$ & 103 & 103 \\
\hline & Punta Espinoza & PEs11 & $1.36^{\circ} \mathrm{S}$ & $89.76^{\circ} \mathrm{W}$ & $11 / 19 / 2004$ & $08: 29$ & 128 & 128 \\
\hline \multicolumn{9}{|c|}{ RV 'Thompson' } \\
\hline \multicolumn{9}{|c|}{ Western region } \\
\hline Transition & West Isabela & BIO1 & $0.62^{\circ} \mathrm{S}$ & $91.70^{\circ} \mathrm{W}$ & $1 / 21 / 2006$ & $17: 45$ & 180 & 3021 \\
\hline \multirow[t]{2}{*}{ cold-warm } & Punta Mangle & $\mathrm{BIO} 2$ & $0.62^{\circ} \mathrm{S}$ & $91.32^{\circ} \mathrm{W}$ & $1 / 23 / 2006$ & $02: 30$ & 140 & 143 \\
\hline & North West Isabela & $\mathrm{BIO} 3$ & $0.23^{\circ} \mathrm{S}$ & $91.39^{\circ} \mathrm{W}$ & $1 / 22 / 2006$ & $14: 00$ & 180 & 2237 \\
\hline \multicolumn{9}{|c|}{ Central region } \\
\hline Transition & North East Isabela & $\mathrm{BIO} 4$ & $0.02^{\circ} \mathrm{S}$ & $91.13^{\circ} \mathrm{W}$ & $1 / 25 / 2006$ & 03:00 & 180 & 2117 \\
\hline cold-warm & Central & $\mathrm{BIO} 5$ & $0.53^{\circ} \mathrm{S}$ & $90.78^{\circ} \mathrm{W}$ & $1 / 24 / 2006$ & $07: 30$ & 180 & 543 \\
\hline \multicolumn{9}{|c|}{ Southeastern region } \\
\hline Transition & Santa Fe & BIO6 & $0.92^{\circ} \mathrm{S}$ & $90.00^{\circ} \mathrm{W}$ & $1 / 21 / 2006$ & $21: 45$ & 180 & 211 \\
\hline cold-warm & South East & XO1 & $2.00^{\circ} \mathrm{S}$ & $89.00^{\circ} \mathrm{W}$ & $1 / 27 / 2006$ & $02: 00$ & 180 & 3110 \\
\hline
\end{tabular}


fluorescence, photosynthetically active radiation, and dissolved oxygen concentration. Niskin bottles were used to take water samples at 5 depths from all stations from the surface to the $1 \%$ light level. These water samples were used to measure nutrient concentrations and to determine phytoplankton size distribution. Nitrate, ammonia, phosphate, and silica were measured using standard procedures (Strickland \& Parsons 1968, Grasshoff et al. 1983, UNESCO 1994, Holmes et al. 1999). Size distribution of phytoplankton was determined by filtering water samples through 20 and $2 \mu \mathrm{m}$ Whatman GF/F filters. Chl a concentrations for each fraction $(<2,2-20$, and $>20 \mu \mathrm{m}$ ) were determined by fluorometry using standard procedures (Newton \& Voorhis 2002). To complement the hydrographic data, SST maps (see Fig. 3) were generated for each sampling month using the State of the Ocean (SOTO) webtool based on GHRSST Level 4 MUR Global Foundation Sea Surface Temperature Analysis v4.1 (NASA/JPL 2015).

\subsection{Laboratory methods}

All zooplankton samples were taken to Oregon State University for laboratory analyses. Sub-sampling was performed with a Stempel pipette, removing $20 \mathrm{ml}$ of sample from $500 \mathrm{ml}$ of total volume. This sub-sample was placed in a miniBogorov counting chamber, and each zooplanktonic organism was identified and counted under a dissecting microscope at $20 \times$ magnification. This sub-sampling method ensured that $>1000$ individuals were counted from each zooplankton sample (total of 40125 organisms). Adult copepods were identified to species level due their relative high abundance and biomass. Immature copepods were identified at least to genus level and to species level when possible. Copepod identifications were largely based on Boxshall \& Halsey (2004) and other taxonomic literature therein in combination with original species descriptions. Other zooplanktonic organisms were tabulated under their major taxonomic groups.

\subsection{Statistical methods}

The 2 data sets, one generated by samples from the PV 'Guadalupe River' cruises and the other generated with samples from the RV 'Thompson' cruises, were analyzed separately because the sampling done aboard the PV 'Guadalupe River' was consistently over the Galápagos shelf, from seafloor depths ranging from 130 to $287 \mathrm{~m}$, most starting at $0-20 \mathrm{~m}$ above the seafloor (Table 1), while those taken aboard the RV 'Thompson' were primarily off the shelf, in oceanic waters, with seafloor depths ranging from 143 to $3021 \mathrm{~m}$ (Table 1) and sampling starting at an average of $1452 \mathrm{~m}$ above the seafloor. Therefore, the communities sampled are different; the PV 'Guadalupe River' targeted coastal zooplankton, while the RV 'Thompson' targeted oceanic zooplankton. Both data sets were standardized by relativization to total zooplankton abundance, converting the data from absolute abundance to relative abundance.

Sampling sites were grouped according to the marine bioregions as identified by Edgar et al. (2004) and the SST zonation as delineated by Harris (1969). Because zooplankton sampling was done aboard vessels of opportunity, it was not possible to have a systematic sampling grid covering the entire geographical regions of the archipelago. This resulted in only 3 groups (Table 1, Fig. 1). The upwelling western region had 1 group, comprised of all sites on the west side of the island of Isabela. The non-upwelling eastern region had 2 groups, a central group and southeastern group and included all sites on the east side of Isabela. These groups were further divided by season. Galápagos SST records are depicted in Fig. 2, demonstrating the distinct seasonality of the Islands, with a cold season that included sites sampled in September 2004, November 2004, and July 2005 (Table 1, Fig. 2); and a warm season, that included sites sampled in February and May 2005 (Table 1, Fig. 2). The samples taken in January 2006 were during a transitional period from cold season to warm season (Table 1, Fig. 2).

The 2006 data set was used to test whether zooplankton have species specific responses to the contrasting environmental variables that distinguish the upwelling system in the west from the non-upwelling system in the east. This was accomplished by habitat modeling using nonparametric multiplicative regression (NPMR) with the software HyperNiche 2.0 (McCune \& Mefford 2009). Zooplankton species abundances and zooplankton biodiversity indices were modeled against environmental variables using NPMR. A local mean with Gaussian weights was used for the NPMR. The resulting models were evaluated by 1000 bootstrap replicates. This analysis could not be replicated with the 2004-2005 data set, since it was not possible to collect environmental data with those samples. 


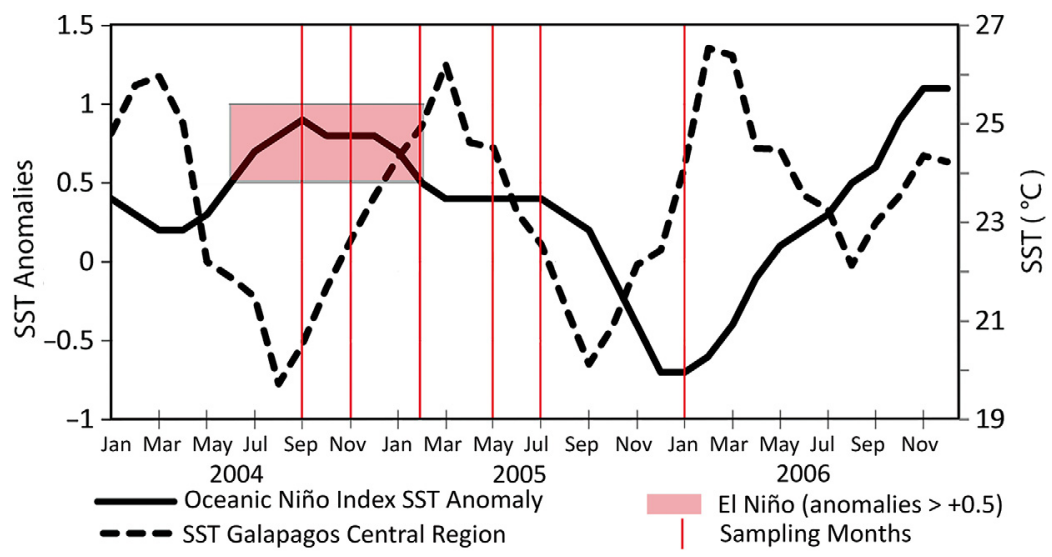

Fig. 2. Oceanic Niño Index, 3 mo running mean of extended reconstructed sea surface temperature (SST) anomalies in the El Niño region $\left(5^{\circ} \mathrm{N}\right.$ to $5^{\circ} \mathrm{S}$, $120-170^{\circ} \mathrm{W}$ ). The highlighted period between June 2004 and February 2005 is considered a mild El Niño based on the anomalies exceeding $+0.5^{\circ} \mathrm{C}$ for 5 consecutive seasons from the 1971-2000 base period (data from NOAA Climate Prediction Center 2021). Monthly mean SST extracted from a $50 \mathrm{~km}$ satellite water pixel from a central site in the Galápagos $\left(1^{\circ} \mathrm{S}\right.$ and $90^{\circ} \mathrm{W}$; data from NOAA Coral Reef Watch 2021). Vertical red lines show months when samples were taken

Both the 2006 and the 2004-2005 data sets were used separately to determine whether the spatial variation of environmental conditions results in distinct zooplankton communities divided geographically into western, central, and southeastern regions. For the 2006 data set, cluster analysis was performed with the software package PC-ORD 5 (McCune \& Grace 2002), using Sorensen distances and flexible-beta as the linkage method. The cluster analysis was used to determine whether the stations clustered based on the predefined regions (western, central, and southeastern). To determine whether the community differences observed were statistically significant, the resulting clusters were analyzed with a non-metric multi-response permutation procedure (MRPP) (Mielke 1984, Dufrene \& Legendre 1997) using the software package PCORD 5 (McCune \& Grace 2002). This test evaluates the null hypothesis of no difference between 2 or more groups by comparing the homogeneity of group members in previously defined groups to the homogeneity of group members in randomly assigned groups (McCune \& Grace 2002). Sorensen distances were used and the distance matrix was changed to ranks before calculating the A-statistic of significance, making it a non-metric MRPP.

The 2004-2005 data set was also used to determine whether the zooplankton community is structured geographically by western, central, and southeastern regions. This was analyzed by ordination based on nonmetric multidimensional scaling (NMS, Kruskal 1964, Mather 1976) using PC-ORD 5. Sites were plot- ted in species space and overlaid with convex hulls based on the regional groupings. The NMS ordination was performed using Sorensen distances. The starting NMS configurations were random, and 1000 runs were performed with the real data. A Monte Carlo test was performed with 250 runs of randomized data. Correlations with the ordination axes of regional distributions and species abundances were determined and represented graphically using joint plots of the sampling sites and species abundances in species space.

To further evaluate community differences based on the geographical groupings, the 2004-2005 data set was also analyzed using MRPP (following the same procedure as described for the 2006 data set) and indicator species analysis (ISA, Mielke 1984, Dufrene \& Legendre 1997). ISA provides a value for each species based on its relative frequency and relative abundance in each group. ISA values can range from 0 to 100 ; a score of 100 means that the presence of that particular species points unequivocally to a specific group (McCune \& Grace 2002). The significance of the indicator value was evaluated with a Monte Carlo test of 1000 randomizations.

Finally, the 2004-2005 data set was also used to test whether the regional zooplankton communities undergo seasonal shifts between a cold and a warm season. This was accomplished by NMS as described above, where sites were plotted in species space and overlaid with convex hulls based on the regional groupings (western, central, and southeastern) and seasons (cold and warm). Because only the western region had good sampling coverage during the warm season, further analyses were limited to samples from that region. Both ISA and MRPP, as described above, were used compare the western community during the cold season to the western community during the warm season.

\section{RESULTS}

\subsection{Oceanographic setting}

The SST maps derived from satellite data and produced by the SOTO 4.5 webtool showed that in September 2004 the SST around the Galápagos is 
the coldest to the west of Isabela, with $\mathrm{SST}<20^{\circ} \mathrm{C}$ (Fig. 3A). To the east temperatures were higher, but still remained relatively cool, with SST ranging from 20 to $24^{\circ} \mathrm{C}$. A cool pool of water $\left(\mathrm{SST}<20^{\circ} \mathrm{C}\right.$ ) was present in the southeast, extending from the South American continent. A warm pool of water (SST > $25^{\circ} \mathrm{C}$ ) was found in the northwest. The SST around the Galápagos during November 2004 remained relatively cool $\left(20-24^{\circ} \mathrm{C}\right)$, but cooler waters (SST < $20^{\circ} \mathrm{C}$ ) were no longer present to the west of Isabela, nor in the southeast near the South American coast (Fig. 3B). The warm pool from the north shifted closer to the islands. By February 2005, the warm pool from the north started to envelop the Galápagos. The coolest temperatures were still west of Isabela, but warmed up considerably (SST $24-26^{\circ} \mathrm{C}$ ), while in the east temperatures were now much higher (SST 26-28 ${ }^{\circ}$ C, Fig. 3C). In May 2005, the entire archipelago, including west of Isabela) was enveloped in warmer waters (SST 26-28 ${ }^{\circ} \mathrm{C}$, Fig. 3D). By July 2005, the warm pool had retreated back north, and cooler conditions developed again, with the west of Isabela reaching the coolest temperatures again (SST < $20^{\circ} \mathrm{C}$ ) and the east slightly warmer (SST $20-24^{\circ} \mathrm{C}$, Fig. 3E). During the January 2006 cruise, the warm pool from the north had started to spread south,

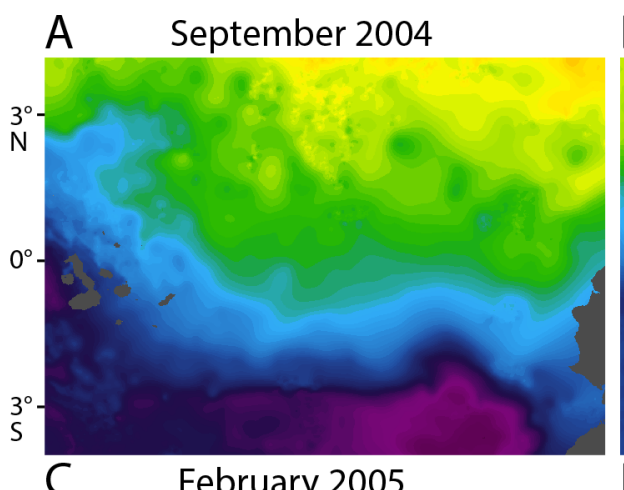

\section{B November 2004}
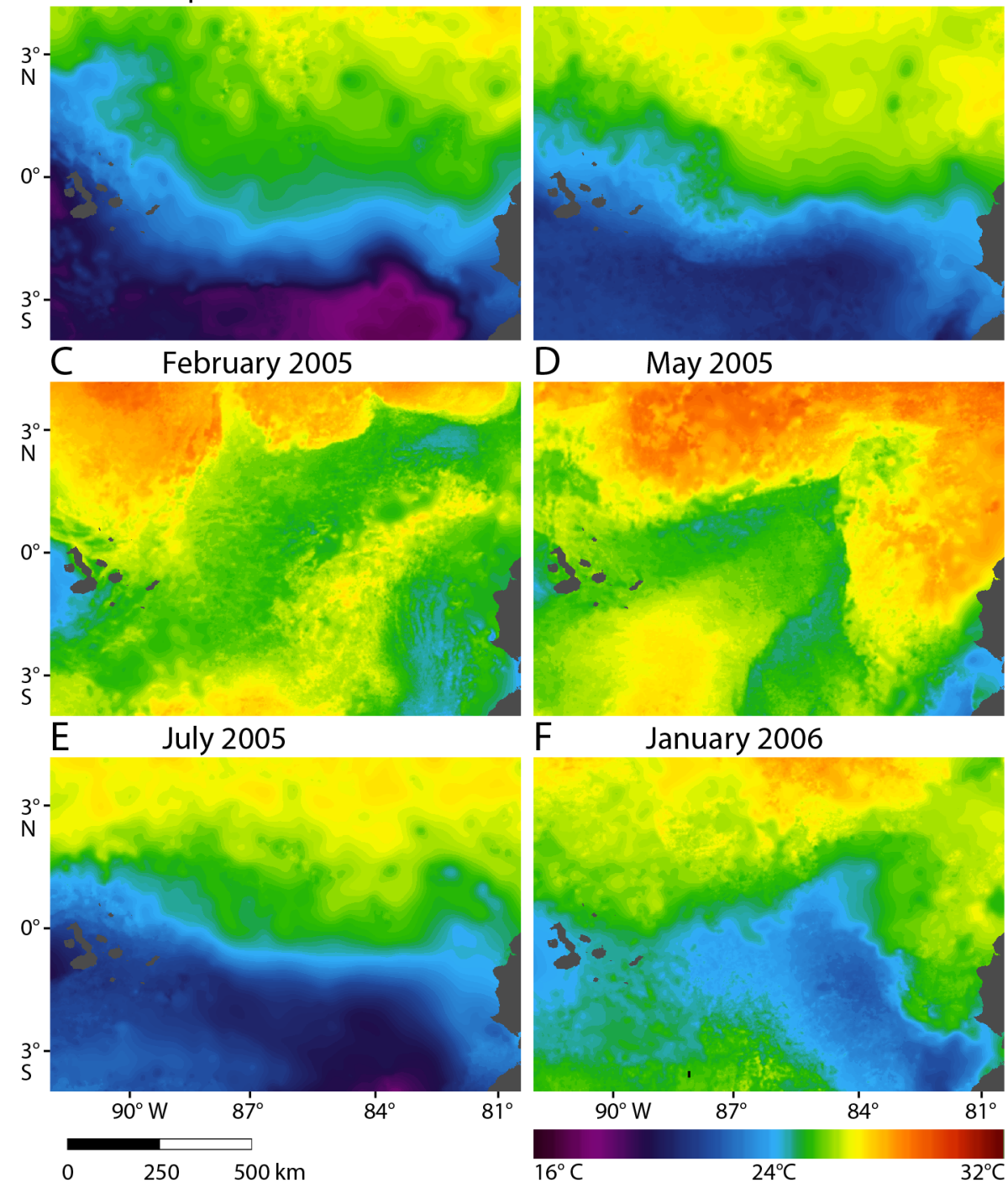

Fig. 3. Sea surface temperature of the region around the Galápagos Islands for each sampling month showing the distribution of water masses and their seasonal progression. (A) September 2004; (B) November 2004; (C) February 2005; (D) May 2005; (E) July 2005; (F) January 2006. Maps generated using the State of the Ocean (SOTO) webtool based on GHRSST Level 4 MUR Global Foundation Sea Surface Temperature Analysis v4.1 (NASA/JPL 2015) 
almost reaching the central islands. The west of Isabella remained relatively cool (SST $20-24^{\circ} \mathrm{C}$ ) while in the east, temperatures were warmer (SST 24-26 ${ }^{\circ} \mathrm{C}$, Fig. 3F).

The hydrographic data recorded by the 2006 research cruise is shown in Fig. 4, including vertical profiles of temperature, salinity, density, oxygen, and chl a concentration (derived from fluorescence) in the upper $70 \mathrm{~m}$ for western (BIO 1-3) and eastern (BIO 4-6 and XO1) stations. Temperature was higher at eastern sites than at western sites, with a welldeveloped thermocline (Fig. 4A). Salinity was lower at eastern sites than at western sites, with a welldeveloped halocline (Fig. 4B). The density was a clear reflection of salinity and temperature, which resulted in lower-density water in the eastern region than in the western region (Fig. 4C). There was much stronger stratification in the east than in the west, with a stark difference in the depth of the pycnocline (2-10 $\mathrm{m}$ in the west and 10-15 $\mathrm{m}$ in the east; Fig. 4C). The oxygen profiles showed higher values at the surface in the western region than in the east, decreasing to $\sim 2.0-2.7 \mathrm{ml} \mathrm{l}^{-1}$ at $50 \mathrm{~m}$ in both regions. The fluorescence, calibrated against extracted pigment concentrations, showed profiles of maxima values near the surface at western sites while eastern sites had a subsurface chlorophyll maximum below the mixed layer (Fig. 4E).

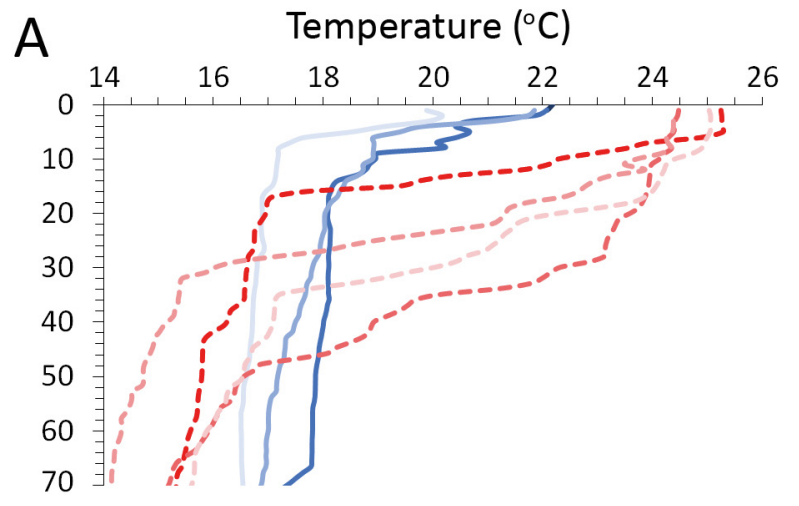

B Salinity (PSU)
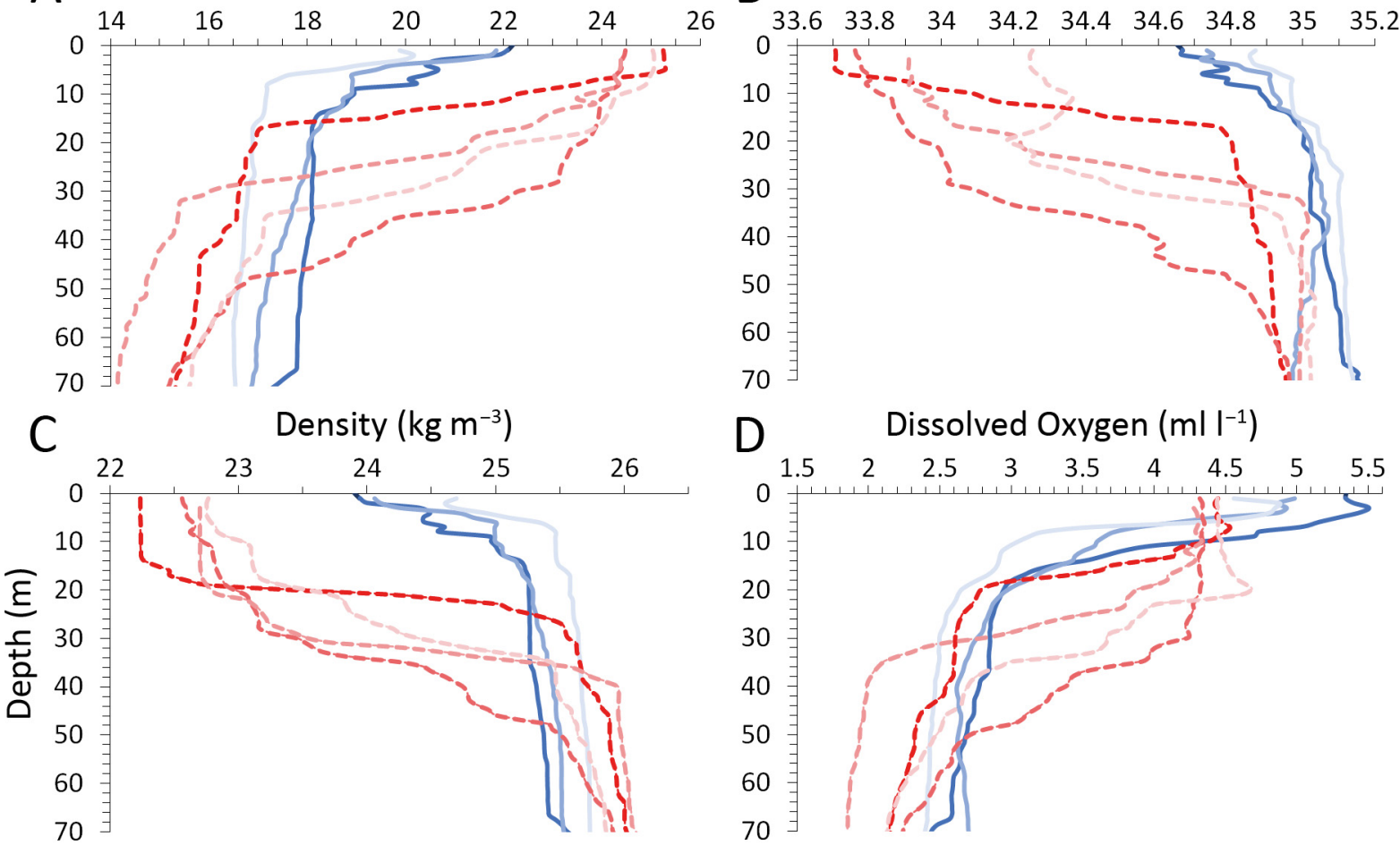

D Dissolved Oxygen $\left(\mathrm{ml} \mathrm{I}^{-1}\right)$
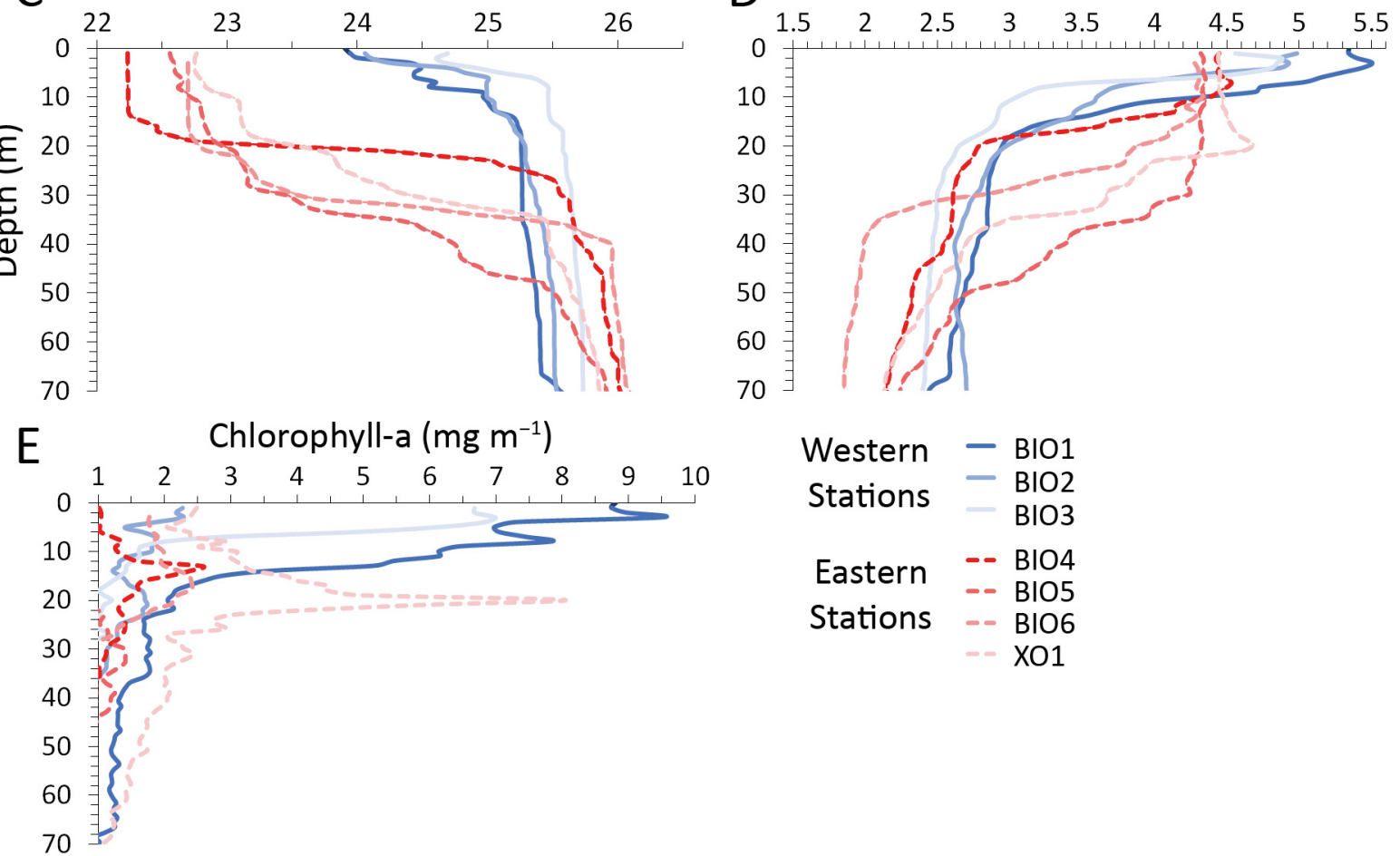

Fig. 4. Vertical profiles (0-70 m) of (A) temperature, (B) salinity, (C) density, (D) oxygen, and (E) chlorophyll $a$ at western and eastern stations measured aboard the RV 'Thompson' during 13-28 January 2006 in the Galápagos Archipelago 
The nutrient profiles in Fig. 5A-D show lower nutrient concentrations at the surface, increasing with depth, except for ammonia, which decreased with depth. There was a faster increase in nitrate concentrations with depth at western than at eastern sites (Fig. 5A). Phosphate concentrations did not show a clear geographic pattern, and their variability was high, with 10-fold higher concentrations at some stations (Fig. 5B). Silica profiles showed low concentrations at the surface, increasing at depth at all stations, and reaching
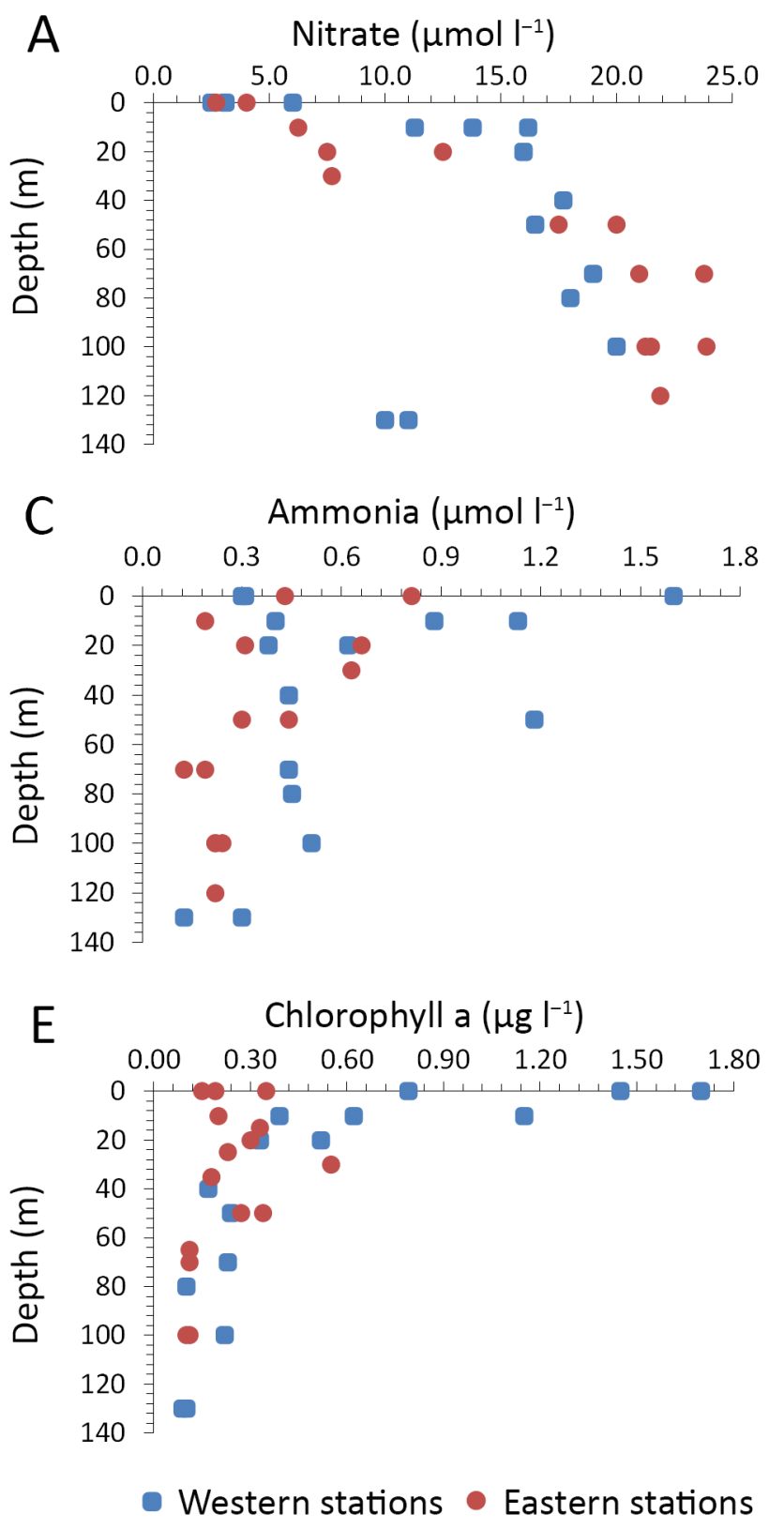

higher concentrations in the eastern region (Fig. 5D). Surface chl a was higher at western stations $\left(0.79-1.7 \mu \mathrm{g} \mathrm{l}^{-1}\right)$ than at eastern stations (0.15-0.35 $\mathrm{ug} \mathrm{l}^{-1}$, Fig. 5E). Chlorophyll decreased steadily with depth at western stations while at eastern stations, chlorophyll levels were low throughout the mixed layer. (Fig. 5E). The size fractionation analysis of chlorophyll showed that most phytoplankton cells were $>20 \mu \mathrm{m}$ at the western stations and $<2 \mu \mathrm{m}$ at eastern stations (Fig. 5F).
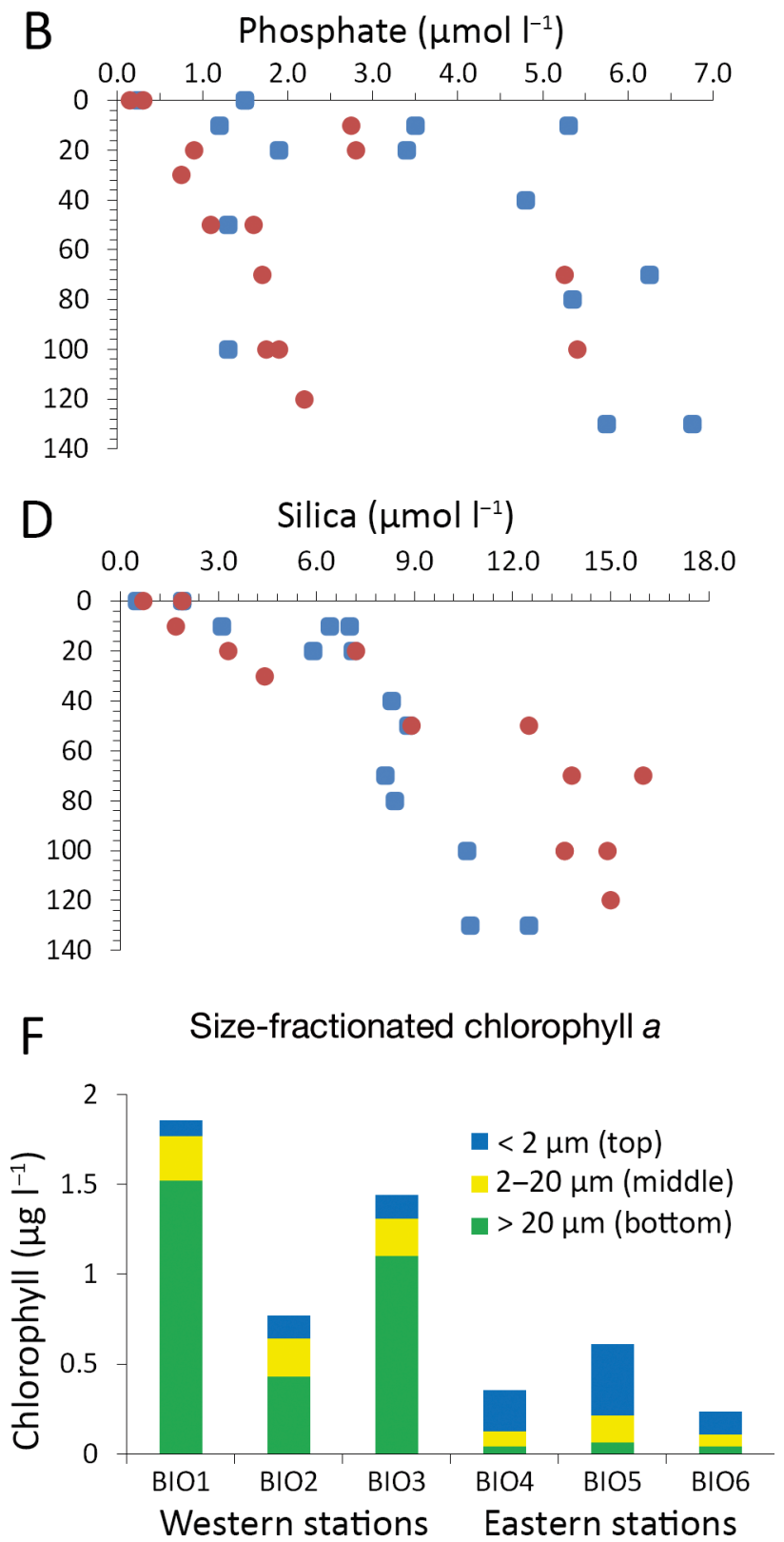

Fig. 5. Vertical profiles of (A) nitrate, (B) phosphate, (C) ammonia, (D) silicate, and (E) chlorophyll a measured aboard the RV 'Thompson' during 13-28 January 2006 in the Galápagos Archipelago. (F) Size-fractionated chlorophyll a 


\subsection{Zooplankton biodiversity}

Copepods were the most abundant zooplankton group representing $90-95 \%$ of the total zooplankton abundance across all regions (Table 2 ; Table S1 in the Supplement, www.int-res.com/articles/suppl/ m661p049_supp.pdf). Chaetognaths and euphausiids were significantly abundant at some stations, contributing up to $6 \%$ of the abundance, but when averaged across all stations, they only contributed 3 and $2 \%$, respectively. Other taxonomic groups contributed $1 \%$ or less to the abundance and included Appendicularia (1\%), Ostracoda $(0.2 \%)$, Polychaeta $(0.2 \%)$, Amphipoda $(0.1 \%)$, Gastropoda $(0.06 \%)$, miscellaneous Crustacea (crab larvae, shrimp larvae, mysids, isopods, $0.7 \%$ ), and others (non-crustaceans such as ctenophores, jellyfish, salps, other mollusks, other annelids, and fish larvae, $0.03 \%$ ). Because of their dominant numbers, species identification focused mainly on copepods. A total of 164 copepod species were identified (Table S1). Each sub-sample contained between 40 and 96 species. There were numerous rare species: 72 species were found at 3 or fewer sites, with 32 having a single occurrence.
Zooplankton species abundance for each geographical region and season for both data sets, 2004-2005 and 2006, are shown in Table S1. Zooplankton abundance and diversity indices for all stations are shown in Table S2. The total zooplankton density ranged from 97 organisms $\mathrm{m}^{-3}$ in north Isabela to 5814 organisms $\mathrm{m}^{-3}$ in southwest San Cristobal. The average number of species per station was 51, with a range of 22 (northwest Isabela) to 82 species (northwest Española). Simpson's diversity index was high for most samples and ranged from 0.67 to 0.95 with an average of 0.88 . About $87 \%$ of the sampling stations had a Simpson's diversity index $>0.8$. The Shannon diversity index ranged from 1.91 to 3.47 , with an average of 2.82. Evenness ranged from 0.51 to 0.84 with an average of 0.73 .

\subsection{Environmental drivers of the zooplankton community}

NPMR of the zooplankton biodiversity indices relative to hydrographic variables resulted in 1 statistically significant model $(\mathrm{p}<0.05$, Fig. 6A). The model showed that $44 \%$ of changes in species rich-

Table 2. Average abundance, percentage, and median of the most numerous groups of Galápagos zooplankton for all regions. The 'Misc. Crustacea' category includes Decapoda, Mysida, and Isopoda. The 'Other' category includes Medusozoa, Ctenophora, Salpidae, Mollusca, Annelida, and fish larvae

\begin{tabular}{|c|c|c|c|c|c|c|c|c|c|}
\hline & \multicolumn{3}{|c|}{ Western region } & \multicolumn{3}{|c|}{ Central region } & \multicolumn{3}{|c|}{ Southeastern region } \\
\hline & $\begin{array}{c}\text { Avg. } \\
\text { (ind. } \mathrm{m}^{-3} \text { ) }\end{array}$ & $\%$ & $\begin{array}{c}\text { Med. } \\
\left(\text { ind. } \mathrm{m}^{-3} \text { ) }\right.\end{array}$ & $\begin{array}{c}\text { Avg. } \\
\text { (ind. } \mathrm{m}^{-3} \text { ) }\end{array}$ & $\%$ & $\begin{array}{c}\text { Med. } \\
\text { (ind. } \mathrm{m}^{-3} \text { ) }\end{array}$ & $\begin{array}{c}\text { Avg. } \\
\text { (ind. } \mathrm{m}^{-3} \text { ) }\end{array}$ & $\%$ & $\begin{array}{c}\text { Med. } \\
\text { (ind. } \mathrm{m}^{-3} \text { ) }\end{array}$ \\
\hline Cold season & \multicolumn{3}{|c|}{$-(8$ stations $)-$} & \multicolumn{3}{|c|}{$\longrightarrow$ (5 stations $)-$} & \multicolumn{3}{|c|}{$-(6$ stations $)$} \\
\hline Copepoda & 1128.30 & 92.82 & 807.06 & 504.30 & 94.00 & 588.17 & 2373.00 & 89.53 & 637.56 \\
\hline Chaetognatha & 0.30 & 0.02 & 0.00 & 20.70 & 3.86 & 27.55 & 173.60 & 6.55 & 5.85 \\
\hline Euphausiacea & 79.40 & 6.53 & 15.23 & 2.30 & 0.44 & 4.06 & 24.70 & 0.93 & 9.12 \\
\hline Appendicularia & 1.10 & 0.09 & 0.00 & 8.10 & 1.52 & 5.41 & 20.60 & 0.78 & 0.99 \\
\hline Ostracoda & 0.20 & 0.02 & 0.00 & 1.00 & 0.18 & 1.05 & 3.00 & 0.11 & 1.17 \\
\hline Polychaeta & 5.10 & 0.42 & 0.00 & 0.00 & 0.00 & 0.49 & 5.10 & 0.19 & 0.00 \\
\hline Amphipoda & 0.00 & 0.00 & 0.00 & 0.10 & 0.01 & 0.16 & 5.90 & 0.22 & 0.00 \\
\hline Gastropoda & 0.00 & 0.00 & 0.00 & 0.00 & 0.00 & 0.00 & 3.20 & 0.12 & 0.00 \\
\hline Misc. Crustacea & 1.00 & 0.08 & 0.00 & 0.00 & 0.00 & 4.78 & 39.60 & 1.50 & 0.00 \\
\hline Other & 0.20 & 0.02 & 0.00 & 0.00 & 0.00 & 0.00 & 1.70 & 0.06 & 0.00 \\
\hline Warm season & \multicolumn{3}{|c|}{$(7$ stations $)$} & \multicolumn{3}{|c|}{$-(1$ station $)$} & \multicolumn{3}{|c|}{$-(1$ station $)-$} \\
\hline Copepoda & 479.10 & 94.23 & 567.46 & 974.60 & 95.38 & 567.82 & 441.60 & 91.38 & 671.11 \\
\hline Chaetognaths & 9.40 & 1.86 & 8.36 & 18.10 & 1.78 & 6.91 & 7.30 & 1.50 & 6.93 \\
\hline Euphausiacea & 3.10 & 0.60 & 3.30 & 8.00 & 0.78 & 3.97 & 16.20 & 3.36 & 10.35 \\
\hline Appendicularia & 11.00 & 2.16 & 4.48 & 17.50 & 1.72 & 17.55 & 15.90 & 3.29 & 8.69 \\
\hline Ostracoda & 2.80 & 0.55 & 4.09 & 2.60 & 0.26 & 2.35 & 1.70 & 0.35 & 2.49 \\
\hline Polychaeta & 0.20 & 0.04 & 0.00 & 0.00 & 0.00 & 0.18 & 0.00 & 0.00 & 0.15 \\
\hline Amphipoda & 0.20 & 0.05 & 0.28 & 0.60 & 0.06 & 0.00 & 0.30 & 0.06 & 0.14 \\
\hline Gastropoda & 0.40 & 0.08 & 0.00 & 0.00 & 0.00 & 0.18 & 0.00 & 0.00 & 0.00 \\
\hline Misc. Crustacea & 1.90 & 0.37 & 0.28 & 0.30 & 0.03 & 5.05 & 0.30 & 0.06 & 0.14 \\
\hline Other & 0.30 & 0.06 & 0.00 & 0.00 & 0.00 & 0.18 & 0.00 & 0.00 & 0.00 \\
\hline
\end{tabular}




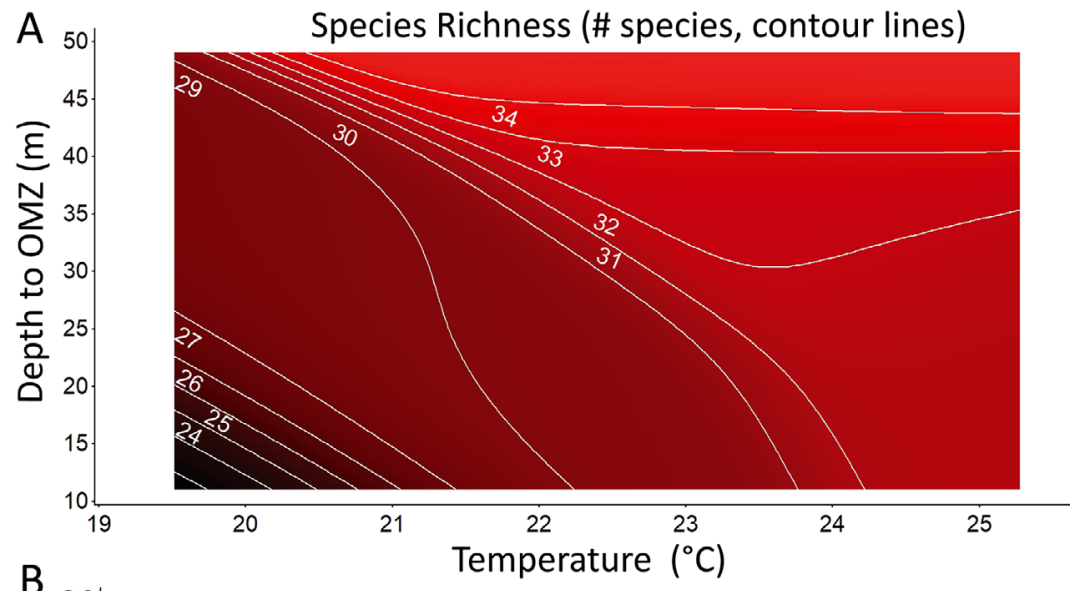

B

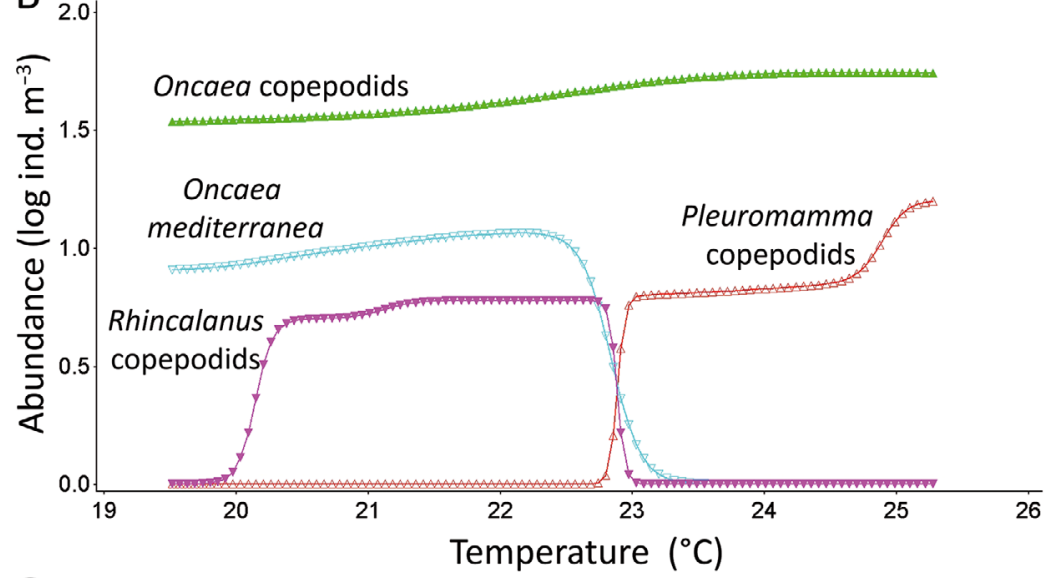

C

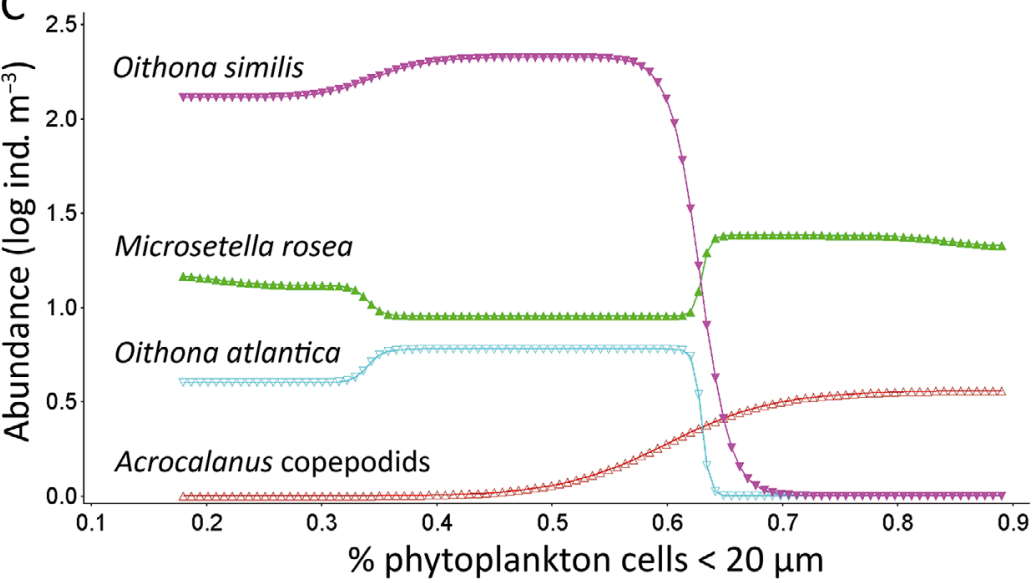

Fig. 6. Nonparametric multiplicative regression plots. (A) Contour plot of species richness relative to temperature and depth to the oxygen minimum zone (OMZ). (B) Abundance response of individual species to temperature. (C) Abundance response of individual species to relative frequency of small and medium phytoplankton cells $(<20 \mu \mathrm{m})$ collected on the RV 'Thompson' during 13-28 January 2006 in the Galápagos Archipelago

ness can be explained by temperature and the depth to the oxygen minimum zone (OMZ). The NPMR plot for this model in Fig. 6A shows that the general trend is increased diversity with increasing temperature and increasing depth to the $\mathrm{OMZ}$, demonstrating that the number of species is greatly influenced by both temperature and depth to the OMZ when temperatures are $<21.5^{\circ} \mathrm{C}$ with a shallow OMZ $(<25 \mathrm{~m})$. Temperature had very little effect on species richness when there was a well oxygenated water column with depths between 25 and $35 \mathrm{~m}$. When there were deep oxygenated waters $(>35 \mathrm{~m})$, temperature had no effect on species richness when it was below $22^{\circ} \mathrm{C}$; a large effect when the temperature was between 22 and $24^{\circ} \mathrm{C}$; and almost no effect at higher temperatures (Fig. 6A). There were no statistically significant models for abundance, evenness, Shannon diversity index, or Simpson's diversity indices.

The NPMR of the zooplankton community data resulted in statistically significant models $(p<0.05)$ for the abundance of 16 of the 104 copepod species found in samples (Table 3). For 10 species, the models were single-variable, and 6 species had 2-variable models. Surface temperature was the variable that best explained the abundance of Oncaea mediterranea (large form) and copepodids of Oncaea, Rhincalanus, and Pleuromamma (Table 3, Fig. 6B). The NPMR plot in Fig. 6B shows that the abundance of $O$. mediterranea increased sharply at cold temperatures $<23^{\circ} \mathrm{C}$, while the abundance of Pleuromamma copepodites dropped sharply to 0 below this temperature. Pleuromamma copepodites increased rapidly around $23^{\circ} \mathrm{C}$ and remained fairly constant until about $25^{\circ} \mathrm{C}$, after which their abundance increased sharply again. Oncaea copepodites showed a steady increase throughout the entire temperature range $\left(19.5-25.5^{\circ} \mathrm{C}\right)$. Rhincalanus copepodites were absent at temperatures below $20^{\circ} \mathrm{C}$; above this temperature, abundance increased rapidly to about $20.5^{\circ} \mathrm{C}$, after which it tapered and slowly increased until about $23^{\circ} \mathrm{C}$. At temperatures higher than $23^{\circ} \mathrm{C}$, Rhincalanus copepodite abundance decreased sharply, to the point that they were absent at higher temperatures. 
Table 3. Nonparametric multiplicative regression of zooplankton species abundances and environmental variables in the Galápagos Archipelago. Models were evaluated by 1000 bootstraps. Only models with $\mathrm{p}<0.05$ are shown. SST: sea surface temperature $\left({ }^{\circ} \mathrm{C}\right)$, OMZD: depth to oxygen minimum zone $(\mathrm{m})$; PycD: pycnocline depth $(\mathrm{m})$; nitrate: nitrate concentration $\left(\mu \mathrm{mol} \mathrm{l} \mathrm{l}^{-1}\right)$; silica: silica concentration $\left(\mu \mathrm{mol} \mathrm{l} \mathrm{l}^{-1}\right)$; $\mathrm{Chl}$ : percentage of chlorophyll cells of a particular size class; ChlCD: chlorophyll cell density $\left(\mu \mathrm{g} \mathrm{l}^{-1}\right)$

\begin{tabular}{|c|c|c|c|c|c|c|}
\hline Species & Cross-validated $\mathrm{R}^{2}$ & Variable 1 & Tolerance & Variable 2 & Tolerance & $\mathrm{p}$ \\
\hline Oncaea copepodite & 0.53 & SST & 1.44 & & & 0.001 \\
\hline Rhincalanus copepodite & 0.31 & SST & 0.29 & & & 0.001 \\
\hline Oncaea mediterranea & 0.98 & SST & 0.58 & & & 0.001 \\
\hline Pleuromamma copepodite & 0.9 & $\mathrm{SST}$ & 0.29 & & & 0.03 \\
\hline Calocalanus sp. & 0.58 & OMZD & 5.7 & & & 0.03 \\
\hline Acrocalanus gibber & 0.67 & $\% \mathrm{Chl}<2 \mu \mathrm{m}$ & 0.15 & & & 0.02 \\
\hline Acrocalanus copepodite & 0.54 & $\% \mathrm{Chl}<20 \mu \mathrm{m}$ & 0.14 & & & 0.001 \\
\hline Oithona similis & 0.99 & $\% \mathrm{Chl}<20 \mu \mathrm{m}$ & 0.07 & & & 0.03 \\
\hline Oithona atlantica & 0.95 & $\% \mathrm{Chl}<20 \mu \mathrm{m}$ & 0.61 & & & 0.001 \\
\hline Microsetella rosea & 0.71 & $\% \mathrm{Chl}>20 \mu \mathrm{m}$ & 0.04 & & & 0.02 \\
\hline Microsetella copepodite & 0.53 & OMZD & 5.7 & Silica & 0.66 & 0.001 \\
\hline Euphausiid larvae & 0.35 & Nitrate & 2.43 & Silica & 0.13 & 0.001 \\
\hline Clausocalanus farrani & 0.71 & Nitrate & 2.13 & Silica & 0.26 & 0.001 \\
\hline Temora copepodite & 0.24 & PycD & 12 & ChlCD 2-20 $\mu \mathrm{m}$ & 0.02 & 0.001 \\
\hline Mecynocera clausii & 0.29 & ChlCD $<2 \mu \mathrm{m}$ & 0.05 & $\%$ Chl 2-20 $\mu \mathrm{m}$ & 0.01 & 0.001 \\
\hline Microsetella norvegica & 0.81 & ChlCD $<2 \mu \mathrm{m}$ & 0.19 & $\% \mathrm{Chl}>20 \mu \mathrm{m}$ & 0.22 & 0.001 \\
\hline
\end{tabular}

Size distribution of phytoplankton cells was the best single predictor for 5 copepod species, Acrocalanus gibber, Acrocalanus copepodites, Oithona similis, O. atlantica, and Microsetella rosea (Table 3, Fig. 6C). The abundance of $A$. gibber increased as the fraction of small-sized phytoplankton cells $(<2 \mu \mathrm{m})$ increased (not shown). The NPMR plot in Fig. 6C shows that Acrocalanus copepodids were absent when the relative frequency of small and mediumsized phytoplankton cells was $<50 \%$. It also shows that the abundance of Acrocalanus copepodites steadily rose beyond this frequency, reaching an asymptote at about $70 \%$. O. similis was found in high numbers when the relative frequency of small and medium phytoplankton cells $(<20 \mu \mathrm{m})$ was $<60 \%$. As their relative frequency increased, the abundance of $O$. similis fell quickly to 0 . In the case of $O$. atlantica, Fig. 6C shows that though not as abundant as O. similis, it had a similar trend, with highest abundances when the relative frequency of phytoplankton cells $<20 \mu \mathrm{m}$ was less than $60 \%$, and absent at higher frequencies. Lastly, Fig. 6C shows that $M$. rosea was fairly abundant when the relative frequency of phytoplankton cells $<20 \mu \mathrm{m}$ was between 20 and $60 \%$. The graph shows a sharp rise beyond $60 \%$ and remains high as the relative frequency increases. Another significant single-variable model was for Calocalanus sp. with depth to the $\mathrm{OMZ}$ as the best predictor of abundance (Table 3). As this depth increased, Calocalanus sp. became more abundant (not shown). For the 6 species with 2-variable models
(Table 3), abundance was better predicted by depth to the OMZ and silica (Microsetella copepodites), surface nitrogen and surface silica (euphausiid larvae and Clausocalanus farrani), pycnocline depth and concentration of medium-sized (2-20 $\mu \mathrm{m})$ phytoplankton cells (Temora copepodites), concentration of small-sized $(<2 \mu \mathrm{m})$ phytoplankton cells and percent medium-sized phytoplankton cells (Mecynocera clausii), and concentration of small-sized $(<2 \mu \mathrm{m})$ phytoplankton cells and percent large-sized phytoplankton cells (Microsetella norvegica).

\subsection{Zooplankton community structure: geographic and seasonal patterns}

The cluster analysis for the 2006 community data resulted in a dendrogram that showed a major split between western (BIO1, BIO2, and BIO3) and eastern (BIO4, BIO5, BIO6, and XO1) sampling sites (Fig. 7). The 4 eastern sites divided further into central (BIO4 and BIO5) and southeastern (BIO6 and XO1) sites. MRPP showed that the communities in these groups were statistically distinct $(\mathrm{A}=0.52, \mathrm{p}=0.009)$.

The NMS ordination for the 2004-2005 community data resulted in an optimum 2-dimensional solution (Fig. 8). The final stress was $10.5(\mathrm{p}=0.004)$. The 2 axes represented $90 \%$ of the variance $\left(r^{2}=0.74\right.$ for axis 1 and $r^{2}=0.16$ for axis 2). The NMS ordination is illustrated in Fig. 8, showing that the various sites divided according to their biological components into 


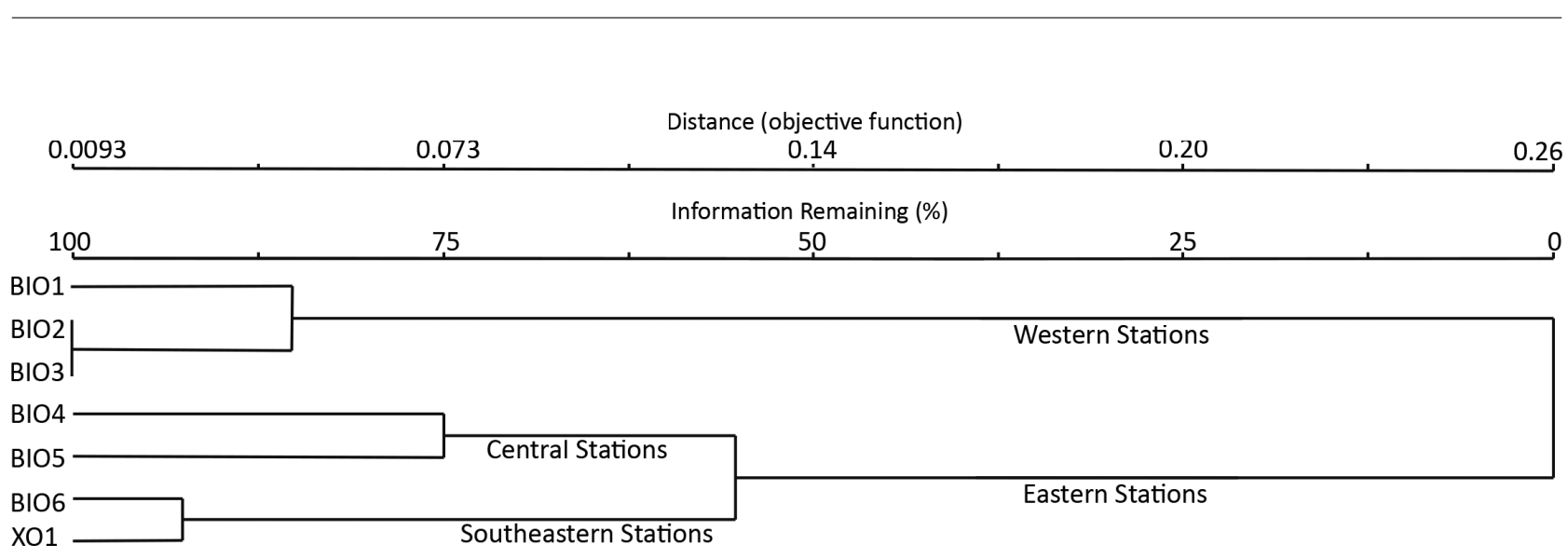

Fig. 7. Relative Sorensen distances for zooplankton species composition collected on the RV 'Thompson' during 13-28 January 2006 in the Galápagos Archipelago. Branching reflects the 3 climate zones sampled. Multi-response permutation procedure analysis shows strong support for these groups $(\mathrm{A}=0.52, \mathrm{p}=0.009)$

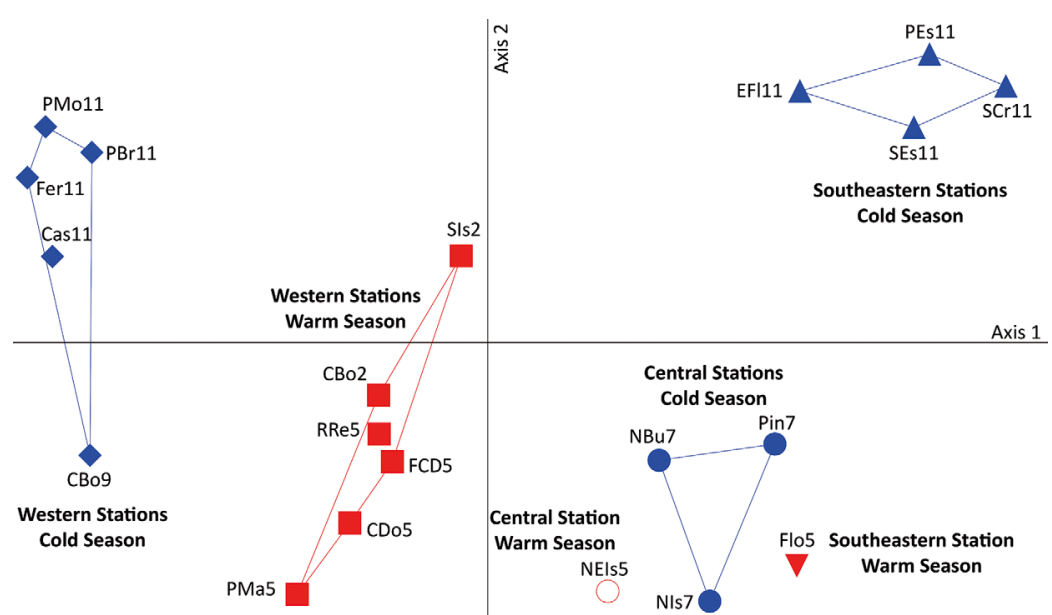

Fig. 8. Non-metric multidimensional scaling ordination of sample units in zooplankton species space during 2004-2005 (zooplankton collected during 2004-2005 in the Galapagos Archipelago). Axes intersection is at the centroid of the cloud of points

4 groups: 3 cold-season groups divided in western, central, and southeastern regions and 1 warm season group consisting of western sites. It also shows that the single central site and single southeastern site sampled during the warm season both clustered near the cold-season central sites. Fig. 8 shows all western sites to the left of the centroid, with those from the cold season in the top left quadrant (except for site CBo9 at the bottom left) and those from the warm season are in the bottom left quadrant (except for Sis2 at the top left), clearly demonstrating that these 4 main groups are significantly separated in species community space.

Zooplankton abundance was correlated with axes 1 and $2(r=0.22$ and 0.60 respectively, Fig. S1) and it was higher at western and southeastern sites during the cold season than at western sites during the warm season. Species richness was positively corre- lated with axes 1 and $2(\mathrm{r}=0.73$ and 0.33 respectively, Fig. S1). The lowest number of species was found at sites west of Isabela during the cold season (Fig. S1). During the warm season, the number of species in the west increased. The highest number of species was found at the southeastern sites. Evenness was correlated to axis 1 ( $r=0.38$, Fig. S1). The abundance of species was more equitable at central and southeastern sites, and less for sites west of Isabela during the cold season. During the warm season the evenness increased in the west, matching that of central and southeastern regions. Axis 1 was correlated to both diversity indices, Shannon $(\mathrm{r}=$ 0.61, Fig. S1) and Simpson $(r=0.31$, not shown). In general, there was greater diversity at central and southeastern sites. Western sites were less diverse during the cold season, but during the warm season, their diversity increased, matching that of eastern sites.

The MRPP for the 3 areas during the cold season showed strong group support, with $\mathrm{A}=0.60$ and $\mathrm{p}<$ 0.0005 . A-values $>0.3$ are considered high (McCune $\&$ Grace 2002), meaning that each group has a unique and distinct biological community. ISA of these groups showed many strong indicators (statistically significant indicators with indicator values [IVs] $>50$, $\mathrm{p}<0.05$ ) for each region: 17 for the western zone, 17 for the central zone, and 20 from the southeastern zone (Table 4).

Due to the limited sampling effort, a regional analysis during the warm season was not possible, but looking only at the western sites, there were 
Table 4. Indicator species analysis. The groups are based on the 3 climate zones sampled during the cold season (western, central, and southeastern) in the Galápagos Archipelago. Indicator values (IV), expressed as \% of perfect indication for each cli mate zone. Only strong and statistically significant indicators (IV $>50 ; \mathrm{p}<0.05)$ are listed

\begin{tabular}{|lclcl|}
\hline Western zone & IV $(\%)$ & Central zone & IV (\%) & Southeastern zone \\
\hline Calocalanus styliremis & 100 & Ditrichocorycaeus affinis & 94 & Neocalanus gracilis \\
Euchaeta acuta & 100 & Candacia copepodids & 88 & Oncaea latimana \\
Oithona attenuata & 100 & Appendicularians & 84 & Hyperiids \\
Oncaea similis & 100 & Lucicutia flavicornis & 82 & Crab and shrimp larvae \\
Oncaea subtilis & 100 & Pleuromamma copepodids & 81 & Clausocalanus farrani \\
Urocorycaeus longistylis & 100 & Scolecithrichidae copepodids & 72 & Oithona plumifera \\
Acartia levequei & 95 & Delibus nudus & 68 & Chaetognaths $(>24$ mm) \\
Paracalanus indicus & 95 & Eucalanus copepodids & 67 & Farranula gibula \\
Oithona similis & 87 & Ditrichocorycaeus minimus & 67 & Scolecithrix danae \\
Rhincalanus copepodids & 87 & Euchirella bella & 67 & Corycaeus speciosus \\
Goniopsyllus sp. & 86 & Subeucalanus pileatus & 67 & Temora discaudata \\
Ditrichocorycaeus dubius & 80 & Calocalanus sp. & 66 & Fish larvae \\
Rhincalanus nasutus & 79 & Candacia pectinata & 63 & Gastropods \\
Euphausiid larvae & 79 & Temoropia mayumbaensis & 63 & Stylocheiron affine \\
Ditrichocorycaeus amazonicus & 79 & Acrocalanus gibber & 63 & Subeucalanus mucronatus \\
Oithona fallax & 68 & Agetus flacus & 59 & Subeucalanus copepodids \\
Microsetella rosea & 65 & Oithona atlantica & 79 \\
& & & 59 & Oncaea venusta \\
& & & & Onychocorycaeus pacificus \\
& & & Corycaeus crassiusculus \\
& & & Paracalanus sp. & 75 \\
\end{tabular}

marked seasonal differences in community composition between the warm and cold season. For this region, the MRPP analysis showed significant differences in species composition between the cold and warm seasons $(A=0.43, p<0.005)$. ISA showed $a$

Table 5. Indicator species analysis for the western zone. The groups are based on the 2 seasons (warm and cold). Indicator values (IV), expressed as \% of perfect indication for each climate zone. Only strong and statistically significant indicators (IV $>50 ; \mathrm{p}<0.05)$ are listed

\begin{tabular}{|llll|}
\hline Warm season & IV & Cold season & IV \\
\hline Chaetognath (<12 mm) & 99 & Ditrichocorycaeus amazonicus & 98 \\
Acartia danae & 96 & Corycaeus crassiremis & 97 \\
Chaetognath $(12-24 \mathrm{~mm})$ & 96 & Acartia levequei & 95 \\
Appendicularians & 95 & Subeucalanus copepodids & 95 \\
Oncaea scotodicalroi & 87 & Parundinella sp. & 93 \\
Agetus flacus & 83 & Paracalanus indicus & 92 \\
Calocalanus tenuis & 82 & Euphausiid larvae & 91 \\
Acrocalanus gibber & 81 & Goniopsyllus sp. & 79 \\
Oithona atlantica & 79 & Microcalanus pusilus & 76 \\
Ostracods (small) & 79 & & \\
Eucalanus copepodids & 78 & & \\
Calocalanus parvus & 78 & & \\
Mecynocera clausii & 77 & & \\
Temoropia mayumbaensis & 77 & & \\
Paracalanus sp. & 73 & & \\
Calocalanus sp. & 72 & & \\
Clausocalanus copepodids & 67 & & \\
Oithona mediterranea & 62 & & \\
(large form) & & & \\
\hline
\end{tabular}

clear seasonal difference in species composition in the west with 18 strong indicators (IV > 50, p < 0.05 ) of the warm season and 9 strong indicators $(\mathrm{IV}>50, \mathrm{p}<0.05)$ of the cold season (Table 5). Of the 18 strong indicators of the warm season, Agetus flacus, Acrocalanus gibber, Oithona atlantica, Temoropia mayumbaensis, Calocalanus sp., Eucalanus copepodids, and appendicularians were also significant indicators of the central zone during the cold season (Table 4). From the 9 strong indicators of the cold season, Ditrichocorycaeus amazonicus, Acartia levequei, Paracalanus indicus, Goniopsyllus sp., and euphausiid larvae were significant indicators of the western zone and Corycaeus crassiremis and Subeucalanus copepodids of the southeastern zone.

\section{DISCUSSION}

The present study demonstrates that the varying zooplankton species-specific responses to abiotic and biotic variables combined with the spatially variable marine environment of the Galápagos result in unique zooplank- 
ton communities whose boundaries are set by the oceanographic features of the archipelago. This is the first taxonomically comprehensive ecological study of zooplankton in the Galápagos Islands. The zooplankton community is dominated by copepods, making up $>90 \%$ of the abundance. Therefore, the biodiversity and ecological patterns of zooplankton reported in this study are driven by the copepod community. It should be noted that the sampling method, specifically the small mesh size used, is most effective at capturing smaller zooplankton such as copepods, and therefore other groups with larger members and stronger swimmers such as Euphausiacea and Chaetognatha and more delicate groups such as Salpida, Ctenophora, and Medusozoa are likely underestimated. Nevertheless, the numerically dominant and diverse copepods of the Galápagos Islands serve as an excellent proxy of the zooplankton community, elucidating clear distributional patterns and seasonal responses to the oceanographic conditions in the Galápagos.

The convergence of 4 major ocean currents in the Galápagos Islands generates a spatially and seasonally heterogeneous marine environment where both local productivity patterns and advection are responsible for shaping the zooplankton community. Three distinct zooplankton communities were observed geographically divided into western, central, and southeastern regions (Fig. 8). The western community was the least diverse; it had the lowest number of species in the archipelago and was dominated by a few abundant copepod species. The central community had higher diversity, higher equitability, but much lower abundances and was primarily composed of smaller, tropical copepod species. The southeastern community was the most abundant and had the highest copepod species richness of the 3 communities, but lower equitability than the central community. These distinct communities are shaped by the physical, chemical, and biological characteristics of the water column over the Galápagos shelf that vary greatly from warm, low-productivity, oligotrophic waters to cool, nutrient-rich, and highly productive waters.

The western region of Galápagos is characterized by strong upwelling due to the surfacing of the EUC through topographic forcing. This upwelling in the western region is usually persistent throughout the year (Palacios 2004, Palacios et al. 2006, Sweet et al. 2007). The hydrographic data for the western region in January 2006 clearly showed the surfacing of the EUC as characterized by the shoaling of the thermocline, cold temperatures $\left(<22^{\circ} \mathrm{C}\right)$, and high salinities
(>34 PSU) typical of this undercurrent (Sweet et al. 2007). The indication of upwelling in the west can also be seen in the SST maps depicted in Fig. 3 for the cold season months. The upwelling and shallow thermocline in this region ensure that the euphotic zone remains well supplied with nutrients. This results in the highest chlorophyll levels recorded in the archipelago during January 2006, with chl a concentration peaking just below the surface. The dominant phytoplankton in this region were large cells such as diatoms, which can take advantage of the frequent and abundant nutrient supply. This highly productive and stable region allows for a few species of copepods to acquire and sustain dominance, decreasing the overall diversity of the zooplankton community while maintaining relatively high abundances. This pattern has been observed in other regions across the ETP (e.g. Longhurst \& Seibert 1972, Décima et al. 2011, Ambriz-Arreola et al. 2012, Gasca et al. 2012, Kozak et al. 2014). The importance of upwelling in establishing biodiversity trends of zooplankton is emphasized by the habitat modeling, which shows that in the Galápagos, the most important predictors of copepod diversity are water temperature and depth of the OMZ. Copepod diversity is the lowest at low temperatures $\left(<22^{\circ} \mathrm{C}\right)$ and shallow OMZ depth $(<25 \mathrm{~m}$, Fig. 6A), conditions typical of upwelling in the ETP (e.g. Cepeda-Morales et al. 2013).

The central region in the east is not a persistent large-scale upwelling system. Although the EUC does meander to the east, it only surfaces in a few localized regions (Houvenaghel 1978, Schaeffer et al. 2008). The central zooplankton community had the lowest abundance of the 3 regions. Overall lower numbers of zooplankton lead to a higher equitability in this community, since abundantly dominant species are not present. The central sites in this study are located in the north. This northern region is under the influence of tropical, oligotrophic waters brought in by the Panama Current (Sakamoto et al. 1998, Palacios 2004). The Panama Current has a greater influence in the Galápagos Archipelago during the austral summer, when southeasterly trade winds slacken and the ITCZ moves south. These warm, low-nutrient waters from the north do not sustain an abundant planktonic community. The high species diversity found in this region was likely due not only to a variable habitat, but also to drift of zooplankton species in this area from tropical waters from the Central American coast. This observation is consistent with previous studies that show a markedly higher zooplankton species richness in oligotrophic 
waters near the equator than in upwelling and more productive equatorial waters (Dessier \& Donguy 1985, Fernandez-Alamo \& Färber-Lorda 2006, Hirai \& Tsuda 2015).

The southeast region presents a unique situation. It has the greatest species richness and the highest abundance in the archipelago. It is not a persistent upwelling system like the west, yet the abundance of zooplankton is higher. It is also not under the influence of tropical waters as in the central region, yet it has more species. The high zooplankton abundance, despite not being an upwelling system, can be explained by the direct influence of the Peru Current that brings cold, nutrient-rich upwelled waters from the South American coast. Strengthening of the Southeast Trade Winds during the Galápagos cold season moves the ITCZ to its northernmost point, resulting in lower SSTs across the archipelago by extending ESW to the north and strengthening the advection of water from the Peru Current into the SEC (Schaeffer et al. 2008, Liu et al. 2014, Glynn et al. 2017). This pattern of cooler waters across the Galápagos during the cold season is clearly evident in the SST maps (Fig. 3). Sakamoto et al. (1998) showed that nitrate levels in the eastern region of the Galápagos are high in the south and steadily decrease to the north, an indication that nutrient-rich waters from the Peru Current might be influencing the southeast region of the Galápagos. Therefore, it is likely that the advection of nutrient-rich waters to the southeastern region of the Galápagos can support a high zooplankton biomass and seeds the Islands with zooplankton species from nearby continental waters, resulting in both high abundance and high species diversity. Expanded sampling in this region through various seasons, along with complementary sampling in the Peru Current along the South American coast would help elucidate the processes responsible for the observed zooplankton diversity and abundance in this region of the Galápagos.

The regional zooplankton communities undergo seasonal shifts between a cold and a warm season as a result of both changes in environmental variables and changes in advective sources. The upwelling intensity from the EUC in the western Galápagos varies seasonally, and it can be completely suppressed during years with strong El Niño (Palacios 2002, 2004, Palacios et al. 2006, Sweet et al. 2007). During the Galápagos warm season, the southeast trade winds subside and the ITCZ or equatorial front moves south (Xie 1994, Schaeffer et al. 2008, Liu et al. 2014, Glynn et al. 2017). The equatorial front sep- arates the warm oligotrophic TSW to the north from the cooler nutrient-rich (from equatorial upwelling) ESW in the south (Glynn et al. 2017). When this oceanic front moves south, the warm oligotrophic waters envelop the Galápagos (Fig. 3), depressing the thermocline and reducing nutrient input to surface waters. The western sites in the present study were sampled in the warm season during a mild El Niño year in 2005. Therefore, these sites were influenced not only by the seasonal southerly movement of warm oligotrophic waters, but likely by less intense upwelling due to the weakening of the EUC, a typical response to El Niño. This resulted in an increase in zooplankton diversity and a decrease in abundance. These effects are supported by the habitat modeling, which shows that copepod diversity increases rapidly at higher water temperatures and OMZ depths $>45 \mathrm{~m}$, both characteristic of warm, nonupwelling, tropical waters (Fig. 6A). Shifts in zooplankton community composition and abundance due to seasonal changes in upwelling intensity have been observed in the past within the ETP (Dessier \& Donguy 1985, Gómez-Gutiérrez et al. 2001, Fernandez-Alamo \& Färber-Lorda 2006, Ambriz-Arreola et al. 2012, Kozak et al. 2014), including the Galápagos (García et al. 1993). García et al. (1993) showed that the high abundance of zooplankton that they observed in the upwelling system west of Isabela markedly decreased during that year's El Niño when upwelling subsided. Similar patterns have been reported elsewhere in the ETP; for example, Kozak et al. (2014) showed a seasonal decrease in copepod abundance in the Central Mexican Pacific when shifting from an upwelling season to a non-upwelling season. These are the same patterns observed in the present study. In the Galápagos, the seasonal changes in upwelling intensity in the western region result in an overall decrease in zooplankton abundance to levels more typical of the non-upwelling central zone of Galápagos.

This decrease in zooplankton abundance also comes with a shift in community composition with higher biodiversity. While some of the dominant taxa (Clausocalanus jobei, Clausocalanus copepodids, Oithona similis, Oithona copepodids, Paracalanus aculeatus, and Paracalanus copepodids) in the cold season remain dominant during the warm season, other dominant taxa (Acartia levequei, Ditrichocorycaeus amazonicus, euphausiid larvae, and P. indicus) were replaced in dominance by a more diverse mix of taxa (Ctenocalanus tageae, Eucalanus copepodids, Euchaeta copepodids, Lucicutia flavicornis, Mecynocera clausii, Oithona atlantica, Oncaea copepodids, 
Oncaea venusta, Calocalanus sp., appendicularians) from the central zone, resulting in a shift from a community dominated by primarily herbivorous species to one dominated by omnivorous species. Such community shifts to lower abundances and greater species diversity with accompanying seasonal changes in coastal upwelling have been well documented in other regions of the ETP (e.g. Gómez-Gutiérrez et al. 2001, Kozak et al. 2014). A similar pattern was observed in oceanic waters by Dessier \& Donguy (1985), who studied the effects of upwelling along the equatorial Pacific on zooplankton diversity and abundance. They showed that chl a concentrations reach their highest abundances during the peak of the upwelling season along the equatorial Pacific. The abundance of copepods also peaks during this period, and the community changes with primarily herbivorous species increasing in relative abundance over primarily carnivorous species. A similar trend has been observed with other taxa; for example, Ambriz-Arreola et al. (2012) looked at seasonal changes in diversity and abundance of euphausiids in the Mexican central Pacific. They showed that euphausiid abundance was correlated with changes in seasonal upwelling, with highest abundances reached during intense upwelling seasons. Euphausiid larvae in the Galápagos are strongly correlated with high nitrogen and silica concentrations, conditions typical of the upwelling system in the west. Euphausiid larvae virtually disappeared in the west during the warm season, when upwelling is considerably reduced in this region. These patterns are consistent with those observed in the Mexican central Pacific (Ambriz-Arreola et al. 2012, 2018).

These zooplankton biodiversity patterns can be partly attributed to species-specific environmental tolerances and to the abundance and relative frequency of specific size classes of phytoplankton (Fig. 6B,C, Table 3). There are varied, speciesspecific, responses of copepod abundance to water temperature in the Galápagos. The abundance of some copepod species is not influenced by temperature (e.g. Oncaea copepodids), some peak at lower temperatures and are entirely absent at higher temperatures (e.g. Oncaea mediterranea), some peak at higher temperatures and are entirely absent at lower temperatures (e.g. Pleuromamma copepodids), and some peak at a medium range of temperatures and are absent at both higher and lower temperatures (e.g. Rhincalanus copepodids, Fig. 6B). These distinct patterns of temperature preferences clearly help establish the observed community structure of zooplankton around the Galápagos Archipelago, with distinct communities between cooler upwelling regions and warmer non-upwelling regions. Further driving the distinction between these communities is the correlation between the abundance of certain copepod species and the abundance of specific size classes of phytoplankton and the relative frequency of these size classes (Fig. 6C, Table 3). The speciesspecific responses demonstrated that the size class of the dominant phytoplankton community is a better predictor of the abundance of certain copepod species than the total phytoplankton biomass, resulting in strong associations of some copepod species with upwelled waters that support high productivity of large cells such as diatoms and of other copepod species to non-upwelling, oligotrophic waters, dominated by small phytoplankton. The associations of abundance of zooplankton and phytoplankton size classes agree with previous research in the ETP reporting higher mesozooplankton abundance and grazing rates associated with larger phytoplankton, with high surface concentrations of diatoms leading to a grazing community dominated by larger zooplankton (Décima et al. 2011, Selph et al. 2011). These observations suggest that when analyzing ecological associations of zooplankton to productivity patterns, using phytoplankton abundance alone may miss species-specific responses; these become readily apparent when phytoplankton abundance is broken down by cell size as in this study.

The seasonal changes in zooplankton community observed in the western region of the Galápagos suggests that local environmental conditions and advection are both important in shaping zooplankton community structure. In this region of the archipelago, 18 warm-season indicator taxa were identified (14 copepod species and 4 other taxonomic groups, Table 4), 7 of which (the copepods Acrocalanus gibber, Agetus flacus, Oithona atlantica, Temoropia mayumbaensis, Calocalanus sp., and appendicularians) are strong indicators of the central region during the cold season. During the cold season, these 7 taxa were not present in the west, but they arrived in this region during the warm season through advection from the central region. The remaining 11 warm-season indicator taxa (the copepods Acartia danae, Calocalanus parvus, Calocalanus tenuis, Mecynocera clausii, Oithona mediterranea, Oncaea scotodicalroi, Clausocalanus copepodids, Paracalanus sp., and small and medium-sized chaetognaths and ostracods) were present in the west during both seasons. Their abundance was rather low during the cold season, but increased with the shifting environmental conditions, becoming some of the most dominant 
species in the west. By sampling adjacent regions that have drastically different environmental parameters and different zooplankton communities, it is possible to discern seasonal shifts in community structure due to environmental conditions influencing the abundance of local species from those due to advection of immigrant species from the neighboring region.

The influences of advection and movement of water masses on the regional distribution of zooplankton in this region was clearly demonstrated by Arcos \& Fleminger (1986), who conducted a detailed study of copepod species near the Galápagos, with sampling sites located in oceanic waters $300 \mathrm{~km}$ to the east and $700 \mathrm{~km}$ to the west of the archipelago. Of the 20 most abundant species presented by Arcos \& Fleminger (1986), 14 were found in the Galápagos in the present study, including Centropages furcatus, C. gracilis, Cosmocalanus spp., Eucalanus hyalinus, Mesocalanus tenuicornis, Nannocalanus minor, Neocalanus gracilis, Rhincalanus nasutus, $R$. rostrifrons, Subeucalanus pileatus, S. subcrassus, S. subtenuis, Temora discaudata, and Undinula vulgaris. The other 6 species reported by Arcos \& Fleminger (1986) were not found in the present study. This is likely because Arcos \& Fleminger (1986) collected samples far from the Galápagos, with half of their samples closer to the South American coast than to the Galápagos Islands. Their sampling also extended from $5^{\circ} \mathrm{S}$ to $5^{\circ} \mathrm{N}$, while the present study sampled a narrower latitudinal range from $2^{\circ} \mathrm{S}$ to $0.6^{\circ} \mathrm{N}$. Therefore, it is not surprising that the species composition differs between the present study and that of Arcos \& Fleminger (1986). Although there may be some different species at play, Arcos \& Fleminger (1986) demonstrated similar patterns to those presented in this research. They showed that the copepod community in the ETP is structured with respect to water masses of different characteristics. Similar to the present study, they demonstrated that species typical of tropical waters are north of the equator during the Galápagos cold season and move south of the equator during the warm season. The effects of immigration of species from distinct water masses on the copepod community are clearly distinguished in the present study from the effects of fluctuations in abundance of local species due to seasonal shifts in environmental characteristics. Both are important drivers of the community structure and diversity of zooplankton.

Beyond the ecological insight provided, this study also contributes the first comprehensive copepod species list for the Galápagos Islands, with 164 spe- cies identified. In addition to 7 undescribed species, there are 22 species previously unreported from the ETP. Most of these (15 species) inhabit the neighboring Central Tropical Pacific: Aetideus acutus, Mesocalanus lighti, Microcalanus pusillus, Bestiolina inermis, B. similis, Calocalanus tenuis, Delibus nudus, Lucicutia gaussae, Scolecithricella orientalis, Oithona attenuata, Ditrichocorycaeus subtilis, Copilia longistylis, C. mediterranea, Vettoria parva, and Sapphirina intestinata. Arcos \& Fleminger (1986) observed high numbers of neritic species at their southwestern stations, sampled in 1967 and 1968, over $700 \mathrm{~km}$ to the southwest of the Galápagos. They postulated that these neritic species may originate from as far west of the Galápagos as the Marquesas Islands, over $5000 \mathrm{~km}$ away, in the Central Tropical Pacific, likely traveling east along the South Equatorial Counter Current (Arcos \& Fleminger 1986). The presence of these Central Tropical Pacific species in the Galápagos Islands supports the hypothesis of Arcos \& Fleminger (1986) of a migratory connection of zooplankton between the Central Pacific and the ETP supported by eastern surface current flow. The other range extensions include 4 species from the western Pacific (Calocalanus longispina, Ditrichocorycaeus minimus, Lucicutia longispina, and Triconia redacta) and 3 species from the southern coast of South America (Ditrichocorycaeus amazonicus, Candacia armata, and Farranula curta). The presence of the Western Pacific species can be similarly explained by Arcos \& Fleminger's (1986) hypothesis of advection by eastward surface current flow, while the presence of species from the South American coast is easily explained by the flow of the Peru Current into the SEC. Intensified marine research in biologically diverse, previously understudied regions, such as the Galápagos, is essential for improving our understanding of the distribution and the biogeography of marine species.

\section{CONCLUSIONS}

This study provides a baseline of the copepod community for future comparison and assessment of the effects of climate change and human influence on zooplankton of the Galápagos Islands. The zonation based on the copepod community structure presented in this research is in general agreement with the main bioregions described by Edgar et al. (2004) based on reef-associated fish and benthic macroinvertebrates, with the caveats that the central-southeastern region be further divided into central and 
southeastern regions, more in line with the earlier marine divisions proposed by Harris (1969), and that at least for the pelagic organisms, the borders of these bioregions are not static, but rather dynamic due to seasonal variability of major currents.

The Galápagos marine environment varies spatially, observing (1) a nutrient-rich upwelling system with a shallow mixed layer and a diatom-dominated phytoplankton community in the west and (2) a nonupwelling system with a deeper mixed layer, lower surface nutrient concentrations, and a phytoplankton community dominated by small cells in the east. This environmental diversity of coastal waters in the Galápagos results in a highly diverse zooplankton community with varying geographical and seasonal affinities within the archipelago. The environmental drivers of community structure of zooplankton in the Galápagos can be divided into 2 types, one where the environmental variables shape the community through an organismal response to these variables, such as species-specific tolerances and availability of resources. The other where the environmental variables are indicative of a particular type of water mass, and the community is shaped by immigrating species brought into the area by incursion of this water mass. The former controls community structure by influencing changes in abundance of local species and the latter by introducing non-local species into the mix.

The zooplankton community in the Galápagos exhibits clear spatial and seasonal structuring that divides geographically into a western community dominated by a few abundant species, a central community with higher species numbers but much lower abundances, and a southeastern community with the highest species richness and highest abundance of all 3 regions. During the warm season, the dominant copepod community in the west is replaced by a mix of species from the central region and overall zooplankton abundance decreases. These community shifts are driven by both changes in local environmental conditions that result in varying and speciesspecific responses and by the advection of immigrant species with biogeographic affinities to distinct water masses. The relative effects of local environmental conditions and advection can be distinguished through the implementation of objective multivariate analyses as presented in this study.

Acknowledgements. I express my sincere appreciation to Oregon State University's Professor Emeritus Charles B. Miller and Professor Harold P. Batchelder for their advice through all facets of this research project. I thank the Galá- pagos National Park Service for their logistical support of this project, especially the former director of the Galápagos Marine Reserve, Mario Piu; the director of Scientific Investigation, Washington Tapia; the director of Applied Marine Investigation, Eduardo Espinoza; and the captain and crew of the patrolling vessel 'Guadalupe River.' I thank University of Washington's Professor Emeritus Roy Carpenter for inviting me to participate in the RV 'Thompson' cruise of Galápagos and to all other senior scientists and graduate and undergraduate students who also participated and made possible all data collection during that cruise. I also thank the Charles Darwin Research Station, especially senior scientist and oceanographer Stuart Banks, for logistical support and technical advice during the field work of this project. In addition, I thank the anonymous reviewers whose suggestions greatly contributed to the clarity and quality of this work. This work was supported in part by an NSF grant to Dr. Charles B. Miller and Dr. Harold P. Batchelder, OCE0221202; and by a NOAA Nancy Foster Scholarship (NA05N0S4291208) and startup funds from UTRGV to D.F.F.

\section{LITERATURE CITED}

Ahlstrom EH (1971) Kinds and abundance of fish larvae in the eastern tropical Pacific, based on collections made on EASTROPAC I. Fish Bull 69:3-77

Ambriz-Arreola I, Gómez-Gutiérrez J, Franco-Gordo MC, Lavaniegos BE, Godínez-Domínguez E (2012) Influence of coastal upwelling-downwelling variability on tropical euphausiid abundance and community structure in the inshore Mexican central Pacific. Mar Ecol Prog Ser 451: 119-136

Ambriz-Arreola I, Gómez-Gutiérrez J, Franco-Gordo MC, Plascencia-Palomera V, Gasca R, Kozak ER, Lavaniegos BE (2018) Seasonal succession of tropical community structure, abundance, and biomass of five zooplankton taxa in the central Mexican Pacific. Cont Shelf Res 168: $54-67$

Arcos F (1981) A dense patch of Acartia levequei (Copepoda, Calanoida) in upwelled Equatorial Undercurrent Water around the Galapagos Islands. In: Richards FA (ed) Coastal upwelling, Vol 1. American Geophysical Union, Washington, DC, p 427-432

Arcos F, Fleminger A (1986) Distribution of filter-feeding calanoid copepods in the Eastern Equatorial Pacific. Calif Coop Ocean Fish Invest Rep 27:170-186

Beers JR, Stewart GL (1971) Micro-zooplankters in the plankton communities of the upper waters of the eastern tropical Pacific. Deep-Sea Res 18:861-883

Blackburn M, Laurs RM, Owen RW, Zeitzschel B (1970) Seasonal and areal changes in standing stocks of phytoplankton, zooplankton and micronekton in the eastern tropical Pacific. Mar Biol 7:14-31

Boxshall GA, Halsey SH (2004) An introduction to copepod diversity. Ray Society, London

* Brinton E (1979) Parameters relating to the distributions of planktonic organisms, especially euphausiids in the eastern tropical Pacific. Prog Oceanogr 8:125-189

Cepeda-Morales J, Gaxiola-Castro G, Beier E, Godínez VM (2013) The mechanisms involved in defining the northern boundary of the shallow oxygen minimum zone in the eastern tropical Pacific Ocean off Mexico. Deep Sea Res I 76:1-12 
Décima M, Landry MR, Rykaczewski RR (2011) Broad scale patterns in mesozooplankton biomass and grazing in the eastern equatorial Pacific. Deep Sea Res II 58:387-399

*Dessier A, Donguy J (1985) Planktonic copepods and environmental properties of the eastern equatorial Pacific: seasonal and spatial variations. Deep Sea Res A 32: 1117-1133

Dufrene M, Legendre P (1997) Species assemblages and indicator species: the need for a flexible asymmetrical approach. Ecol Monogr 67:345-366

Edgar GJ, Banks S, Fariña JM, Calvopiña M, Martínez C (2004) Regional biogeography of shallow reef fish and macro-invertebrate communities in the Galapagos archipelago. J Biogeogr 31:1107-1124

Fernandez-Alamo M (1983) Los poliquetos pelágicos (Annelida-Polychaeta) del Pacífico Tropical Oriental: Sistemática y Zoogeografía. Tes. Doct., Universidad Nacional Autónoma de México, Mexico City

Fernandez-Alamo M (2000) Tomopterids (Annelida: Polychaeta) from the eastern tropical Pacific Ocean. Bull Mar Sci 67:45-53

Fernandez-Alamo M, Färber-Lorda J (2006) Zooplankton and the oceanography of the eastern tropical Pacific: a review. Prog Oceanogr 69:318-359

Figueroa DF (2011) Two new calanoid copepods from the Galapagos Islands: Pseudocyclops juanibali N. SP. and Pseudocyclops saenzi N. SP. J Crustac Biol 31:725-741

Figueroa DF, Hoefel KL (2008) Description of two new species of Ridgewayia (Copepoda: Calanoida) from Anchialine Caves in the Galapagos Archipelago. J Crustac Biol 28:137-147

García ML, Larrea G, Aguirre C, Vásquez A (1993) Zooplankton biomass, zooplankton and ichthyoplankton abundances around Galapagos Islands in 1983-1984. Rev Cienc Mar Limnol 3:17-18

*Gasca R, Franco-Gordo C, Godínez-Domínguez E, SuárezMorales E (2012) Hyperiid amphipod community in the Eastern Tropical Pacific before, during, and after El Niño 1997-1998. Mar Ecol Prog Ser 455:123-139

Giesbrecht W (1895) Die pelagischen Copepoden. In: Report of the dredging operations off the west coast of central America to the Galapagos, to the west coast of Mexico, and in the Gulf of California, in charge of Alexander Agassiz, carried out by the U.S. Fish Commission steamer "Albatross", during 1891, Lieut. Commander Z.L. Tanner, U.S.N. commanding. Bull Mus Compar Zool Harvard 25:243-263

Glynn PW, Wellington GM (1983) Corals and coral reefs of the Galapagos Islands. University of California Press, San Diego, CA

Glynn PW, Manzello DP, Enochs IC (eds) (2017) Coral reefs of the Eastern Tropical Pacific: persistence and loss in a dynamic environment. Springer Netherlands, Dordrecht

Gómez-Gutiérrez J, Palomares-García R, Hernández-Trujillo S, Carballido-Carranza A (2001) Community structure of zooplankton in the main entrance of Bahía Magdalena, México during 1996. Rev Biol Trop 49:545-557

Grasshoff K, Ehrhardt M, Kremling K (1983) Methods of seawater analysis. Verlag Chemie, New York, NY

* Grice GD (1964) Two new species of calanoid copepods from the Galapagos Islands with remarks on the identity of three other species. Crustaceana 6:255-264

Harris MP (1969) Breeding season of sea birds in the Galapagos Islands. J Zool 159:145-165
Hidalgo P, Escribano R, Fuentes M, Jorquera E, Vergara O (2012) How coastal upwelling influences spatial patterns of size-structured diversity of copepods off central-southern Chile (summer 2009). Prog Oceanogr 92-95:134-145

* Hirai J, Tsuda A (2015) Metagenetic community analysis of epipelagic planktonic copepods in the tropical and subtropical Pacific. Mar Ecol Prog Ser 534:65-78

Holmes R, Aminot A, Keroul R, Hooker B, Peterson B (1999) A simple and precise method for measuring ammonium in marine and freshwater ecosystems. Can J Fish Aquat Sci 56:1801-1808

Houvenaghel GT (1978) Oceanographic conditions in the Galapagos archipelago and their relationships with life on the islands. In: Boje R, Tomczak M (eds) Upwelling ecosystems. Springer-Verlag, New York, NY, p 181-200

Jackson MH (1993) Galapagos: a natural history. University of Calgary Press, Calgary

Kessler WS (2006) The circulation of the eastern tropical Pacific: a review. Prog Oceanogr 69:181-217

Kozak ER, Franco-Gordo C, Suárez-Morales E, PalomaresGarcía R (2014) Seasonal and interannual variability of the calanoid copepod community structure in shelf waters of the Eastern Tropical Pacific. Mar Ecol Prog Ser 507: 95-110

Kruskal JB (1964) Nonmetric multidimensional scaling: a numerical method. Psychometrika 29:1-27

* Liu Y, Xie L, Morrison JM, Kamykowski D, Sweet WV (2014) Ocean circulation and water mass characteristics around the Galápagos Archipelago simulated by a multiscale nested ocean circulation model. Int J Oceanogr 2014: 198686

Longhurst AR (1976) Interactions between zooplankton and phytoplankton profiles in the eastern tropical Pacific Ocean. Deep-Sea Res Oceanogr Abstr 23:729-754

* Longhurst AR, Seibert D (1972) Oceanic distribution of Evadne in the eastern Pacific (Cladocera). Crustaceana 22:239-248

*Manríquez K, Escribano R, Hidalgo P (2009) The influence of coastal upwelling on the mesozooplankton community structure in the coastal zone off Central/Southern Chile as assessed by automated image analysis. J Plankton Res 31:1075-1088

Mather PM (1976) Computational methods of multivariate analysis in physical geography. J. Wiley \& Sons, London

McCune B, Grace JB (2002) Analysis of ecological communities. MjM Software Design, Gleneden Beach, OR

McCune B, Mefford M (2009) HyperNiche V. 2.1. 3, Nonparametric multiplicative habitat modeling. MjM Software Design, Gleneden Beach, OR

Mielke PW Jr (1984) Meteorological applications of permutation techniques based on distance functions. In: Krishnaiah PR, Sen PK (eds) Handbook of statistics, Vol 4. Elsevier Science Publishers, New York, NY, p 813-830

NASA/JPL (2015) GHRSST Level 4 MUR Global Foundation Sea Surface Temperature Analysis (v4.1). https://podaac. jpl.nasa.gov/dataset/MUR-JPL-L4-GLOB-v4.1

Newton J, Voorhis KV (2002) Seasonal patterns and controlling factors of primary production in Puget Sound's Central Basin and Possession Sound. Wash State Department Ecol

NOAA Climate Prediction Center (2021) National Weather Service Climate Prediction Center, El Niño/Southern Oscillation (ENSO). NOAA/National Weather Service, College Park, MD. https://origin.cpc.ncep.noaa.gov/ (updated daily) 
NOAA Coral Reef Watch (2021) NOAA Coral Reef Watch Version 3.1 Daily 5km Satellite Regional Virtual Station Time Series Data for Galapagos, Ecuador, Jan. 2004-Dec. 2006. (Updated daily). NOAA Coral Reef Watch, College Park, MD. https://coralreefwatch.noaa.gov/product/vs/ data.php

Palacios DM (2002) Factors influencing the island-mass effect of the Galápagos Archipelago. Geophys Res Lett 29:2134

Palacios DM (2004) Seasonal patterns of sea-surface temperature and ocean color around the Galápagos: regional and local influences. Deep Sea Res II 51:43-57

Palacios DM, Bograd SJ, Foley DG, Schwing FB (2006) Oceanographic characteristics of biological hot spots in the North Pacific: a remote sensing perspective. Deep Sea Res II 53:250-269

Sakamoto CM, Millero FJ, Yao W, Friederich GE, Chavez FP (1998) Surface seawater distributions of inorganic carbon and nutrients around the Galapagos Islands: results from the PlumEx experiment using automated chemical mapping. Deep Sea Res II 45:1055-1071

Schaeffer BA, Morrison JM, Kamykowski D, Feldman GC and others (2008) Phytoplankton biomass distribution and identification of productive habitats within the Galapagos Marine Reserve by MODIS, a surface acquisition system, and in-situ measurements. Remote Sens Environ 112:3044-3054

Editorial responsibility: Antonio Bode,

A Coruña, Spain

Reviewed by: 3 anonymous referees
Segura-Puertas L (1984) Morfología, sistemática y zoogeografía de las medusas (Cnidaria: Hydrozoa y Sciphozoa) del Pacífico Tropical Oriental. Instituto de Ciencias del Mar Y Limnología, Universidad Nacional Autónoma de México, Publicación Especial 8:1-320

* Selph KE, Landry MR, Taylor AG, Yang EJ and others (2011) Spatially-resolved taxon-specific phytoplankton production and grazing dynamics in relation to iron distributions in the Equatorial Pacific between 110 and $140^{\circ} \mathrm{W}$. Deep Sea Res II 58:358-377

Strickland JDH, Parsons TR (1968) Determination of reactive silicate. Bull Fish Res Board Can 167:65-70

* Suárez-Morales E, Franco-Gordo C, Saucedo-Lozano M (2000) On the pelagic copepod community of the central Mexican tropical Pacific (Autumn, 1990). Crustaceana 73:751-761

Sweet WV, Morrison JM, Kamykowski D, Schaeffer BA, Banks S, McCulloch A (2007) Water mass seasonal variability in the Galápagos Archipelago. Deep Sea Res I 54: 2023-2035

UNESCO (1994) Protocols for the Joint Global Ocean Flux Study (JGOFS) core measurements. Manual and Guides 29. Intergovernmental Oceanographic Commission, Scientific Committee on Oceanic Research, UNESCO, Paris

Xie SP (1994) Oceanic response to the wind forcing associated with the Intertropical Convergence Zone in the northern hemisphere. J Geophys Res 99:20393-20402

Submitted: October 24, 2019

Accepted: December 15, 2020

Proofs received from author(s): March 1, 2021 